\title{
Biologically Enhanced Carbon Sequestration: Research Needs and Opportunities
}

Lead Authors: Curtis M. Oldenburg (LBNL) and Margaret S. Torn (LBNL)

Contributing Authors:

\section{Terrestrial Carbon Sequestration}

Kristen DeAngelis (LBNL), Ron Amundson (UCB), Carl Bernacchi (UIUC), Eoin Brodie (LBNL), Martin Carerra (BP), Atul Jain (UIUC), Markus Kleber (Oregon State), Kevin O'Hara (UCB), Bill Parton (Colorado State), Whendee Silver (UCB), Johan Six (UCD), Tetsu Tokunaga (LBNL), David Zilberman (UCB).

\section{Geologic Carbon Sequestration}

Jonathan Ajo-Franklin, Gillian Bond (NMT), John Christensen (LBNL), Al Cunningham (MSU), Bruce Fouke (UIUC), Terry Hazen (LBNL), Kevin Knauss (LBNL), Seiji Nakagawa (LBNL), Will Stringfellow (LBNL), Tianfu Xu (LBNL)

\section{Suggested citation:}

Oldenburg, C.M., M.S. Torn, K.M. DeAngelis, J.B. Ajo-Franklin, R.G. Amundson, C.J. Bernacchi, G.M. Bond, E.L. Brodie, M. Carerra, J.N. Christensen, A.B. Cunningham, B. Fouke, T.C. Hazen, A.K. Jain, M. Kleber, K.G. Knauss, S. Nakagawa, K.L. O'Hara, W.J. Parton, W.L. Silver, J.W. Six, W.I. Stringfellow, T.K. Tokunaga, T. Xu, and D. Zilberman (2008). Biologically Enhanced Carbon Sequestration: Research Needs and Opportunities. Report on the Energy Biosciences Institute Workshop on Biologically Enhanced Carbon Sequestration, October 29, 2007, Berkeley, CA.

March 21, 2008 


\section{INTRODUCTION}

Fossil fuel combustion, deforestation, and biomass burning are the dominant contributors to increasing atmospheric carbon dioxide $\left(\mathrm{CO}_{2}\right)$ concentrations and global warming. Many approaches to mitigating $\mathrm{CO}_{2}$ emissions are being pursued, and among the most promising are terrestrial and geologic carbon sequestration. Recent advances in ecology and microbial biology offer promising new possibilities for enhancing terrestrial and geologic carbon sequestration.

A workshop was held October 29, 2007, at Lawrence Berkeley National Laboratory (LBNL) on Biologically Enhanced Carbon Sequestration (BECS). The workshop participants (approximately 30 scientists from California, Illinois, Oregon, Montana, and New Mexico) developed a prioritized list of research needed to make progress in the development of biological enhancements to improve terrestrial and geologic carbon sequestration. The workshop participants also identified a number of areas of supporting science that are critical to making progress in the fundamental research areas.

The purpose of this position paper is to summarize and elaborate upon the findings of the workshop. The paper considers terrestrial and geologic carbon sequestration separately. First, we present a summary in outline form of the research roadmaps for terrestrial and geologic BECS. This outline is elaborated upon in the narrative sections that follow. The narrative sections start with the focused research priorities in each area followed by critical supporting science for biological enhancements as prioritized during the workshop. Finally, Table 1 summarizes the potential significance or "materiality" of advances in these areas for reducing net greenhouse gas emissions.

\section{SUMMARY OF RESEARCH ROADMAP}

\section{Terrestrial Ecosystems and Soil Sequestration}

The highest priority research topics are:

1. Soil C stabilization in deep soil horizons (below $20 \mathrm{~cm}$ )

a. Controls on deep soil carbon stabilization (deep root inputs, mineral interaction, and microbial processing)

b. Modeling and predicting deep soil carbon cycling

c. Inorganic soil carbon sequestration

2. Applications of deep rooted perennials (i.e., bioenergy, reforestation, and restoration)

3. Black carbon stabilization and interface with biofuels lifecycle

4. Understanding and managing the consequences of land use and land cover change

We advocate a three-pronged research program:

1. Synthesis and analysis of existing data (1-3 year projects at $\$ 80-150 \mathrm{k} / \mathrm{y}$ )

a. Patterns of soil organic carbon storage with depth, climate, cover, and land use

b. Evaluation of black carbon opportunities in biofuel 
c. Integration of data and databases for managed lands

2. Experiments to test hypotheses regarding stabilization controls and to test BECS approaches (3-5 year projects at $\$ 100-500 \mathrm{k} / \mathrm{y}$ )

a. Mineral, root, carbonate, silicate, microbial, and redox hypotheses

b. Soil $\mathrm{C}$ turnover time (isotopic) studies within biofuels experiments

c. Testing BECS approaches in field trials

3. Developing, testing, and applying models (2-4 year projects at $\$ 150 \mathrm{k} / \mathrm{y}$ )

a. Ecosystem carbon cycle models for deep soil carbon

b. Ecosystem carbon cycle models for land use and land cover change

c. Integrated assessment models for economic applications

\section{Geologic Carbon Sequestration}

The highest priority research topics are:

1. Mitigation of well leakage and well cement degradation

a. Engineered biofilms to decrease permeability

b. Engineered biofilms to promote carbonate mineral precipitation

2. Microbial interactions with mineral surfaces

a. Enhance cation release for fixation of $\mathrm{CO}_{2}$ in carbonate minerals

3. Enzymatic approaches

a. Use carbonic anhydrase to accelerate carbonate mineral formation

The following supporting science is critical to success:

1. Microbial community structure and function

a. Characterize the microbial community in one or two deep saline formations that are under consideration for geologic carbon sequestration

2. Microbial survivability and stress response

a. Evaluate the impacts of $\mathrm{CO}_{2}$ and associated combustion byproducts on microbes at in situ reservoir conditions

3. Microbial transport

a. Investigate starvation-enhanced microbial transport

4. Geophysical monitoring

a. Use laboratory test-bed for measurement of geophysical parameters crucial to understanding BECS at in situ pressure-temperature (PT) conditions

5. Modeling and prediction

a. Develop coupled biogeochemical reaction networks to predict chemical and biological changes in the formation waters, as well as reactions involving minerals, coatings, and cements

$\underline{\text { Research activity needs and approaches }}$

1. High-priority research areas, and supporting science in the microbial characterization, survivability, and transport areas

a. Laboratory equipment for high PT flow-through and batch reactors

b. Samples of fluids and core from prospective geologic carbon sequestration sites 
c. Standard systems biology tools

d. Experimental studies of 3-4 years duration carried out by small teams

2. Geophysical supporting science

1. Test-bed for integrated geophysical measurements

2. 2-3 year studies by a small team

3. Modeling and prediction

a. Build upon existing modeling frameworks to develop numerical models

b. Begin work 0.5-1 year after other tasks to utilize collected data

c. Development work by a small team over 2-3 years will achieve objectives

\section{Terrestrial Carbon Sequestration}

\section{Background}

Why soils? Soils are the largest and most stable reservoir of terrestrial C, containing about twice as much $\mathrm{C}$ as does the biomass or the atmosphere (Figure 1). Perhaps more important than sheer quantity, annual C fluxes into (via net primary productivity, NPP) and out of (via decomposition to $\mathrm{CO}_{2}$ ) soils are almost ten times larger than fossil-fuel combustion emissions, which means that managing even a small change in gross fluxes yields significant sequestration benefits. For these reasons, the promise of BECS is widely recognized (for example, see IPCC WGIII 2007). Furthermore, there is a potential win/win opportunity for forestry, rangeland, and agriculture, including bioenergy crop production, in that BECS in soils is also expected to lead to greater plant production and sustainability through improved fertility, water holding capacity, and soil structure. The potential for positive and negative environmental or socio-economic effects of terrestrial sequestration should be considered. Moreover, the conversion to bioenergy crops-and the change in land management they engender-could inadvertently lead to large amounts of soil $\mathrm{C}$ transferred to the atmosphere if the controls on soil $\mathrm{C}$ storage are not well understood.

Which soils? More than $25 \%$ of earth's land area is currently managed for food, fuel, or fiber, or has been degraded by such use (FAO 2005; Goldewijk and Ramankutty 2004). These managed and degraded lands present an immediate and promising opportunity for near-term terrestrial $\mathrm{C}$ sequestration, because of the potential to rebuild and possibly surpass historical $\mathrm{C}$ stocks through management of the biological, chemical, and physical soil environment. Moreover, these lands tend to be associated with advantageous infrastructure, economic linkages, cultural practices, political or regulatory permissions, and lower biodiversity risks relative to unmanaged systems. There are many different ecosystems in which $\mathrm{C}$ sequestration may be practical, including: forests managed for $\mathrm{C}$ offsets, timber forests, food agriculture, rangeland, and bioenergybiomass production.

While specific $\mathrm{C}$ sequestration opportunities may vary, there is a common set of underlying research needs to enable BECS in most or all systems. As a result, we conclude that a focused research effort on a few strategic topics would create large opportunities for $\mathrm{C}$ sequestration in systems that are amenable (physically, ecologically, economically, and politically) to $\mathrm{C}$ management in the next 5-10 years. 
Carbon can be sequestered by increasing plant inputs (net primary productivity; NPP) and/or by reducing decomposition (i.e., increasing turnover time, $\tau$; Figure 2 ). We focus on the latter (increasing $\tau$ ) for two reasons. First, it is a larger and more significant gap in our understanding of BECS; agricultural science and forestry have long directed efforts at maximizing NPP. In contrast the potential for soil $\mathrm{C}$ sequestration has only recently begun to be explored. Second, NPP varies by only a factor of 10 globally (between deserts and tropical forests) whereas soil $\tau$ can vary by a factor of 1,000 between the soil surface and one-meter deep, or among regions. Third, $\mathrm{C}$ stabilized in soils has the potential be a much longer-term sink than $\mathrm{C}$ stored in plant tissues, particularly in food or fiber crops. Finally, stabilization is likely to be more consistent (compared to relying on enhanced NPP) on an annual basis and thus easier to predict and certify.

Below we describe (1) the opportunity (materiality), (2) the priority research needs to realize that opportunity; and (3) modeling and integrated assessment priorities that will make terrestrial $\mathrm{C}$ sequestration applications economically and environmentally sensible.

\section{MATERIALITY: SEQUESTRATION OPPORTUNITY In MANAGED ECOSYSTEMS}

The potential magnitude of BECS in soils has been estimated by various groups at roughly $4 \mathrm{Pg} \mathrm{C} / \mathrm{y}$ globally. Table 1 summarizes some of the sequestration opportunities in managed ecosystems and the type of research needed to realize the sequestration potential. Based on a series of research road maps, the sequestration opportunities for forests, rangelands, agricultural fields, biomass croplands, and deserts and degraded lands are significant and are mainly related to increasing soil $\mathrm{C}$ storage (although plant biomass is important for forest and degraded lands).

\section{Priority Soil Carbon-Sequestration Research.}

\section{Controls on carbon stabilization in deep soil horizons}

Most research on soil organic $\mathrm{C}$ has been limited to the top $20 \mathrm{~cm}$ of soil, for logistical reasons and the assumption that most soil $\mathrm{C}$ is found near the surface. New assessments of soil $\mathrm{C}$ stocks estimate that there is 1,300-1,600 Pg C in the top meter and an additional $900 \mathrm{Pg} \mathrm{C}$ below that (Batjes 1996; Jobbágy and Jackson 2000) not counting permafrost and peatlands (Zimov et al., 2006). There remains great uncertainty, however, in the inventory of $\mathrm{C}$ stored below the surface, and basic research is needed to understand the relationship of these $\mathrm{C}$ stocks to ecological factors. This research should take the form of synthesis and analysis of existing data coupled with experiments to test hypotheses regarding controls.

Besides being relatively isolated from disturbances, such as wildfire or tillage that might threaten aboveground or near surface ecosystem $\mathrm{C}$ stocks, deep soil $\mathrm{C}$ is also characterized by extraordinarily long residences times (commonly up to 10,000 y) as measured by radiocarbon analysis. Radiocarbon clearly shows that soil $\mathrm{C}$ residence times increase with depth (Figure 3). Currently, there are four competing (though not necessarily exclusive) hypotheses for explaining this trend: (1) lack of fresh, labile plant input that would catalyze microbial activity and decomposition (this effect of labile plant 
inputs is known as priming); (2) redox conditions that are unfavorable for decomposition; (3) organo-mineral associations providing stabilization; and (4) input of inherently recalcitrant (or readily stabilized) $\mathrm{C}$ from deep roots or dissolved organic carbon (DOC). Without testing these hypotheses, it is not possible to know, for example, which soils have the most potential for further $\mathrm{C}$ sequestration, or whether changes in management will promote or undermine $\mathrm{C}$ storage.

In summary, understanding what controls enhanced residence time of soil $\mathrm{C}$ with depth would allow:

- Development of methods to enhance $\mathrm{C}$ sequestration

- Evaluation of $\mathrm{C}$ storage potential and residence time

- Identification of near-term opportunities for BECS

- Development of practices for quantification and certification

These are the goals of our research agenda on deep soil organic carbon.

\section{$\underline{\text { Soil C stabilization in deep soil horizons (below } 20 \mathrm{~cm} \text { ) }}$}

The spatial and temporal trends of heterotrophic respiration (decomposition) across the whole soil profile determine the flux of $\mathrm{CO}_{2}$ diffusing to the soil surface and emitted to the atmosphere. Although the relationship between vertical variation in $\mathrm{C}$ dynamics and temporal variation in surface $\mathrm{CO}_{2}$ fluxes is evident, the mechanisms governing $\mathrm{C}$ dynamics at depth and $\mathrm{CO}_{2}$ efflux are poorly understood and quantified. One of the reasons that so little is known is that there is are so few observations of the patterns of soil properties (such as soil temperature, soil moisture, soil structure, $\mathrm{O}_{2}$ concentration, microbial community composition and activity) across the whole soil profile, in conjunction with $\mathrm{C}$ inputs and residence times and $\mathrm{CO}_{2}$ production.

The gaps in knowledge of $\mathrm{C}$ dynamics at depth prevent reliable predictions of the effect of ecosystem management and global change on $\mathrm{C}$ dynamics in deeper soil layers and ultimately surface-to-atmosphere $\mathrm{CO}_{2}$ fluxes. Even a small change in $\mathrm{C}$ input rate to subsurface layers, or in decomposition rates of the $\mathrm{C}$ stored at depth, could lead to large changes in soil-to-atmosphere $\mathrm{CO}_{2}$ fluxes (which the current generation of soil organic matter (SOM) models would not be able to predict). Therefore, there is an urgent need to integrate experimental work with model development to elucidate and quantify $\mathbf{C}$ dynamics at depth and its direct influence on surface $\mathrm{CO}_{2}$ fluxes. Experimental research should aim to reveal the spatial and temporal changes in the environmental driving factors that control SOM dynamics across the whole soil profile extending beyond the vertical spatial scale of 20 to $50 \mathrm{~cm}$ depth traditionally used in SOM research and models. These data would support new modeling approaches that integrate the effect of deep soil $\mathrm{C}$ dynamics with soil-to-atmosphere $\mathrm{CO}_{2}$ fluxes. In return, the use of novel process-based modeling techniques is essential for furthering our understanding of the relative importance of the various factors influencing $\mathrm{C}$ dynamics across the whole soil profile, and subsequently extending the hourly and/or daily time scale of measurements to yearly and decadal time scales needed for management and policy decisions. 


\section{$\underline{\text { 3. Deep rooting plant carbon inputs to soil }}$}

\section{Synergisms: Deep soil C, microbes}

Roots and the changes they effect on soil biogeochemistry through deposition of exudates, known as the rhizosphere effect, are critical to both the storage and stability of $\mathrm{C}$ in soil. Increasing deep root growth and $\mathrm{C}$ inputs may be a promising sequestration strategy. First, root biomass itself can be a large $\mathrm{C}$ stock. Root biomass exceeds aboveground biomass in many ecosystem types, and when rhizosphere biota are included, the belowground fraction of plant-derived $\mathrm{C}$ may far surpass the aboveground fraction (Lynch and Whipps, 1990). The net effect of the rhizosphere (the root-influenced zone of soils) on soil C stocks is complicated by myriad interactions and feedbacks. High proportions of photosynthate $\mathrm{C}$ end up in the microbial biomass in surface soils (Cheng and Gershenson, 2007). While past studies have estimated microbial biomass at less than $5 \%$ of soil C in surface soils, modern NMR spectroscopy suggests that this is a gross underestimate (Simpson et al., 2007). Additionally, the high metabolic activity of rhizosphere-soil microbial communities can be responsible for 30-50\% of $\mathrm{CO}_{2}$ emissions as respiration from soil, depending on plant type, ecosystem, climate, and depth (Kuzyakov, 2006; Cheng and Gershenson, 2007).

Depositing carbon deep in soil via deep roots is likely the most ecologically sound and most cost-effective method of adding organic $\mathrm{C}$ to the deep soil. The mean residence time in soil of litter inputs from roots is more than twice that of shoots, due to a combination of physical and chemical interactions of roots and rhizodeposits, the mechanisms of which are still being elucidated (Rasse et al., 2005). Perennial biomass crops are excellent candidates for increased $\mathrm{C}$ sequestration; not only do they tend to be deeply rooting species with the potential of fixing much more $\mathrm{CO}_{2}$ than shallow-rooting species, but the aboveground biomass may also serve as a bioenergy source. However, movement of significant amounts of photosynthate-derived $\mathrm{C}$ into the deep soil (by planting deeply rooting species like Miscanthus) may activate deep soil microbial communities (i.e., priming) and cause increased decomposition of the stable deep SOM, offsetting the $\mathrm{C}$ benefits. This priming effect is uncertain at a fundamental level: it is not known whether or when labile plant inputs from roots would increase decomposition of older soil organic matter.

Research is required to investigate how deep-rooting plants affect soil C stability, including indirect effects of roots on soil carbon cycling, effects on microbial community composition, microbial biomass, oxygen availability, and labile organic C. Understanding the potential of deep rooting for enhancing sequestration is a feasible research goal over the next five years, where a combination of laboratory experiments and field soil depthprofiles could inform where and to what extent soil $\mathrm{C}$ can be stabilized by deeply rooting species most effectively.

\section{Organo-mineral interactions}

Soil carbon can be stabilized for thousands and tens-of-thousands of years through associations with mineral surfaces (Torn et al., 1997). In the absence of a mechanistic understanding, many soil scientists and all soil models use soil texture (i.e., the amount of clay-sized particles) as a proxy for this process. However, in tests of soils from over 20 temperate and tropical locations, we consistently find that mineral reactivity, rather than 
mineral texture, is a better predictor of the amount and turnover time of stable (passive) soil carbon, and can be associated with 2-3 fold differences in total soil C storage (Kahle et al., 2004, Mikutta et al., 2005, Kleber et al., 2004, Kleber et al., 2005, Mertz et al., 2005; Torn et al., 1997; Masiello et al., 2004, Rasmussen et al., 2005). Unfortunately, we are not prepared to integrate these features into sequestration planning quite yet. We need better understanding of exactly which mineral constituents are important for stabilization, what the capacity of a soil is (or saturation level is), and what the mechanisms of stabilization are.

Mineral surfaces in soils are mainly provided by the very small particles $(<2 \mu \mathrm{m})$ that constitute the clay fraction. This fraction is a mixture of phyllosilicates, oxides and hydroxides, and, in some soil types, short-range order minerals like allophane and imogolite. Traditional concepts were highly focused on the role of phyllosilicates as dominating mineral surfaces for the formation of organo mineral associations (e.g., Stevenson, 1982; Theng, 1979). Later, total mineral surface area has been considered as a predictor for the amount of OM (organic matter) that is stabilized in soils (Mayer et al., 1994a; Saggar et al., 1996; Hassink, 1997; Six et al., 2004), but an understanding of the relationship between mineralogy and the chemistry of OM bound in organo-mineral associations is still lacking. Most of the data available are from loamy arable topsoils, while there is little information on other soil types and the distribution with depth (Lützow et al., 2006). A major step forward would be to conduct research combining soil mineralogical, organic chemical, and microbial research approaches.

Increasing evidence demonstrates the influence of soil biota in the formation of organo-mineral assemblages (Chenu and Stotzky, 2002). Here, the ability of microorganisms to standardize mineral surfaces to their needs by "active support preconditioning" (Bos et al., 1999; Dufrene et al., 1996) seems to promote mineralorganic associations through the deposition of extracellular polysaccharides and proteins as adhesives. It is well known that numerous Gram-negative and Gram-positive bacteria exude extracellular polymeric substances (EPS) into their environment. (Omoike and Chorover, 2006). In natural aqueous environments, pristine mineral surfaces become coated rapidly by biogenic organic films (Bos et al., 1999). The formation of these "conditioning films" moderates eventual differences in the surface chemistry of the underlying substrate and can thus be seen as an adaptation mechanism that allows microorganisms to colonize highly variable types of mineral surfaces. It has become evident that soil microorganisms as well as soil enzymes are heterogeneously distributed within the soil matrix (Kandeler and Dick, 2006). Still, little detailed information is available on the spatial distribution of soil micro-biota. This spatial variability and heterogeneity in the distribution of microorganisms and soil organic matter with regard to the mineral surfaces requires new experimental approaches to the investigation of possible interactions between organic matter and mineral surfaces. Another suggestion for future research is to put more emphasis on the elucidation of the mechanisms at the organic matter-mineral interface.

More studies of organo-mineral associations-including how to isolate them, characterize them, and determine their stability, as well as the distribution of organo-mineral compounds in soils from different ecosystems - are needed. These qualities, the distribution and content of organic matter in different soils/ecosystems, and its 
composition and stability in organo-mineral associations need to be evaluated in relation to the distribution of microorganisms and microbial enzyme activities at organo-mineral surfaces. In addition to involving field work and experiments, such work requires specialized facilities such as the Advanced Light Source (high energy x-ray imaging) and the Centers for Isotope Geochemistry and Stable Isotope Biogeochemistry at LBNL and UCB.

\section{Ecosystem Modeling: Soil carbon cycling below $20 \mathrm{~cm}$ depth}

Jobbagy and Jackson's (2000) analysis of the vertical distribution of soil carbon showed that soil carbon concentrations are much higher in the 0-20 cm depth, however, large amounts of carbon are found in the deeper soil layers (20-300 cm depth). At a global scale, they suggest that climatic factors primarily control carbon stocks in the shallow layers, while soil texture is quite important for deep carbon pools. Trumbore et al. (1995), and others have shown that the mean residence time (mean age) of soil carbon dramatically increases with soil depth for most regions. Their results suggest that there are depth-dependent changes in decomposition rates and turnover of soil organic matter pools (See also Bruun et al., 2007; Gill and Burke 2002). Potential factors contributing to the observed higher stability of carbon with increasing soil depth include: (1) less favorable decomposition rates with increasing soil depth, resulting from changes in soil moisture, temperature, and litter quality; (2) depth-dependent changes in the soil carbon stabilization processes; and (3) transport of stable organic matter down the soil profile caused by diffusion (water flow, soil animals, mixing, and other processes).

Hunt (1977) attempted to model the changes in soil C levels with depth and included the impact of changes in soil water and temperature with soil depth, depth distribution of root inputs to the soil, and diffusion transport of soil organic matter down the soil profile. He concluded that depth-dependent changes in soil water and temperature could not account for the observed drop in litter decay with depth, and that soil decomposition rates would have to decrease by a factor of eight between the near surface $(0-4 \mathrm{~cm})$ and deeper soil layers $(15-60 \mathrm{~cm})$ to account for lower soil respiration rates in the deeper soil layers. Recent research suggests that transportation of resistant organic matter down the soil profile can explain the observed increase in C age with depth (Baisden 2007; Baisden et al., 2002). The scientific uncertainties about the role of different processes in controlling formation of soil organic matter in deep soil make it very difficult to accurately model soil carbon changes with depth in natural and managed ecosystems (Parton et al., 1998) .

One of the main scientific goals of the EBI program should be to design experiments that will allow determination of the relative importance of the different soil processes in controlling depth-dependent changes in soil-organic-matter distribution. The results from this research will be critical for development of models that simulate soil carbon stabilization in deeper soil layers.

\section{Microbial communities, enzymes, and activities}

Soil microbes play two critical roles in soil carbon cycling, each of which must be understood to manage soil carbon sequestration. First, microbes (and microbial enzymes) are the agents of decomposition that transform plant inputs into complex humic matter, which is more stable than the original plant inputs (Parton and Silver et al., 2007). The 
origin of this humic material may be from microbial cell walls that are recalcitrant or readily stabilized, or they may be the abiotic chemical agglomerization of smaller, reactive carbon species. Microbes in soil also use organic $\mathrm{C}$ for respiration and are the main agent of loss of soil carbon to the atmosphere as $\mathrm{CO}_{2}$, also called $\mathrm{C}$ mineralization. Specific rhizosphere microbial community constituents are correlated with net $\mathrm{C}$ mineralization rates (Fierer et al., 2007), suggesting that changes in microbial community composition could influence $\mathrm{C}$ stabilization.

We need fundamental research on the types of microbes involved in $\mathrm{C}$ cycling and the processes by which they produce recalcitrant $\mathrm{C}$ or readily stabilized soil $\mathrm{C}$. For example, if cell wall material is the most important source of stabilized $\mathrm{C}$, it will be important to understand what microbial taxa produce such cell walls and how their stabilization depends on the mineral component of soil. Advanced molecular technologies can identify the roles of specific organisms to access different fractions of organic matter. These modern molecular methods make it possible to know the mechanisms of microbially driven carbon cycling at the microbial or molecular level. Thus, only recently has it become possible to accomplish the investigations involving microbes that are suggested here.

\section{Inorganic carbonate}

Although the major reservoir of carbon on Earth's surface is soil organic carbon (SOC), inorganic $\mathrm{C}$ constitutes a significant and even dominant fraction of the soil $\mathrm{C}$ inventory in many soils (Nettleton, 1991). The soil carbonate mineral fraction is typically in the form of calcium carbonate $\left(\mathrm{CaCO}_{3}\right.$, as calcite), and can amount to several percent of the total soil mass. Thus, stimulation of calcite precipitation may have large $\mathrm{C}$ sequestration capacity in some soils. Calcite precipitation is promoted under nonacidic, semi-arid and arid conditions, and where net infiltration of soil water to underlying groundwater is limited.

Because $\mathrm{Ca}^{2+}$ and $\mathrm{HCO}_{3}{ }^{-}\left(\mathrm{CO}_{3}{ }^{2-}\right)$ concentrations drive calcite precipitation, some rhizosphere (root zone) soil environments may be managed to sequester significant quantities of $\mathrm{C}$. Being the zone of active plant root and soil microbial respiration, the rhizosphere is also elevated in $\mathrm{CO}_{2}$ partial pressure, hence enriched in bicarbonate $\left(\mathrm{HCO}_{3}{ }^{-}\right)$(Rendig, 1989). Many decades of agricultural practice have demonstrated that the shallow rhizosphere is particularly suitable to beneficial and cost-effective additions of $\mathrm{Ca}^{2+}$ amendments (Shainberg and Shalhevet, 1984). In addition to driving calcite precipitation, $\mathrm{Ca}^{2+}$ is an essential plant nutrient, stabilizing soil aggregates through flocculation of clay minerals, thereby improving soil moisture and nutrient supply to plant roots (Rendig 1989). Moreover, $\mathrm{Ca}^{2+}$ stabilizes SOC-mineral associations (Huang and Schnitzer, 1986). Thus $\mathrm{Ca}^{2+}$ supplied to promote $\mathrm{C}$ sequestration through $\mathrm{CaCO}_{3}$ mineral formation may also enhance crop productivity and support SOC sequestration. These synergistic impacts of stimulating $\mathrm{CaCO}_{3}$ precipitation in soils make accelerating inorganic $\mathrm{C}$ sequestration worthy of investigation.

The possibility of sequestering inorganic $\mathrm{C}$ within and immediately below the rhizosphere of biomass energy fuel crops such as Miscanthus and switchgrass, and other agricultural and natural systems, is attractive because it employs a pathway that runs parallel to SOC sequestration, has a high capacity, diminishes soil respiratory $\mathrm{CO}_{2}$ fluxes 
back to the atmosphere, and can have synergistic effects on both biomass production and SOC stability. While numerous studies on calcite precipitation have been done on simple systems, the complexity of the open rhizosphere/soil systems will require systematic experiments in order to determine optimal conditions and rates of inorganic $\mathrm{C}$ sequestration.

\section{Black carbon}

Once considered only for mining lands and other specialty applications, biochar has recently been proposed as a major approach to sequestration, particularly in concert with bioenergy biomass production and conversion (Amonette et al., 2003). Biochar (also known as black $\mathrm{C}$ and charred $\mathrm{C}$ ) is pyrolized or partially combusted organic material under limited oxygen availability, which maintains high $\mathrm{C}$ concentrations as well as other nutrients. There are several avenues by which biochar could enhance sequestration. First, biochar is thought to make the soil more fertile, enhancing $\mathrm{C}$ in soils due to increased plant growth. Second, biochar is considered relatively stable, having a longer residence time than the uncharred precursor material (however, there is an uncertainty of a factor of ten on these values). Finally, there is some evidence to suggest that biochar acts to stabilize other organic matter in soil, much as a mineral surface might. Research on the Amazon terra preta soils (that received biochar amendments during pre-Columbian times) compared to unamended soils nearby continue to show increased fertility and $\mathrm{C}$ sequestration as well as differences in soil microbial community fingerprint (Lehmann et al., 2003; Kim et al., 2007). Not only does biochar present a significant BECS opportunity, preliminary data suggest that application of biochar to soils attenuates nitric oxide and methane emissions, both potent greenhouse gases (Lehman, 2007).

Research is needed in several areas to evaluate the application of biochar for enhanced $\mathrm{C}$ sequestration. Research must be conducted to investigate industrial and lowtech modes of producing char, including the amount of $\mathrm{C}$ that is lost to the atmosphere in the process, and to make sure that toxic compounds (for microbes, plants, or people) are not produced inadvertently. The agricultural application of biochar needs to also be investigated. The few studies available all show increased plant productivity and soil $\mathrm{C}$ stabilization with the addition of biochar, but more rigorous studies must be conducted in different managed ecosystem types. Finally, the long-term stabilization of C by way of biochar must be understood by elucidating the mechanisms of stabilization and where it would be most useful. The ancillary benefits to this approach, namely synergies with the biofuels lifecycle and the use of biochar as an environmentally sound fertilizer that could be accessible in less developed countries, make biochar an attractive mode of BECS that merits further investigation.

\section{Carbon sequestration by plant opal phytoliths: Questions and potential}

Native plants (especially grasses) and various cultivars have the ability to preferentially extract dissolved silica from the soil solution and mineralize it, from the plant transpiration stream, in leaves, fruit, and other tissues. These silica bodies (the poorly crystalline mineral opal) usually contain, embedded within their structure, $<1 \%$ of the total organic $\mathrm{C}$ in the plant. While this quantity of $\mathrm{C}$ is small, once the plant material is added to soil, the dissolution rate of the phytoliths is likely an order of magnitude slower than the rate of decomposition of plant material not contained in these minerals. 
Studies have shown that in certain grasslands, $70 \%$ of total soil $\mathrm{C}$ that cycles on millennial scales is made of phytolith-associated $\mathrm{C}$.

These observations and data suggest that the growth of cultivars capable of producing large concentrations of phytoliths may enhance soil $\mathrm{C}$ sequestration through slow buildup of phytolith-protected organic matter. However, important research needs to be conducted to assess this potential, answering the following questions:

1. What is the phytolith production capability of various target plants for biofuel production?

2. What is the root-to-shoot difference in phytolith production?

3. How susceptible are phytoliths to dissolution during biofuel processing?

4. What is the dissolution rate of processed vs. unprocessed phytoliths?

5. How does phytolith production by cultivars differ from previous crops (e.g., corn and soybeans) or native vegetation (tall grass in Illinois, for example).

6. What is the existing quantity of phytolith-associated $\mathrm{C}$ in targeted soil?

7. How do changes in soil fertility practices between perennial crops vs. corn affect the weatherability of opal phytoliths (e.g., soil pH and types of acids)?

In summary, the conversion of lands to long-term perennial grass crops may-under certain or even most conditions - result in a slow and steady sink of organic $\mathrm{C}$ in soils that has turnover times of $10^{3}$ years. This question is at least deserving of some intensive pilot research, establishing background information to determine whether a larger scale research project is warranted.

\section{Synthesis and analysis: Patterns of soil organic carbon stabilization and storage with depth, climate, cover, and land use}

There is a great opportunity to advance BECS simply by synthesizing existing data on soil carbon cycling and environmental conditions. There are two main foci of this research priority: (1) patterns in $C$ sequestration, and (2) effects of land use. The first objective would be to establish knowledge and gaps regarding soil carbon pools and turnover. This effort would focus on mechanisms driving patterns in soil $\mathrm{C}$ storage and loss, moving beyond strictly descriptive summaries. This objective would help identify near-term opportunities and further research priorities for BECS.

The second objective would focus on identifying ecosystem characteristics, such as soil type, climate, and land cover, that influence the effect of land conversion on soil $\mathrm{C}$ pools and fluxes. As with objective one, the focus should be on mechanisms driving patterns and change such as the role of land use history, effects of plant functional types, climate/soil moisture, soil texture, root depth, and plant chemistry. There is a pressing need to better understand the mechanisms that drive greenhouse gas emissions with land cover change, so that the direct and indirect effects of expanded biomass production can be rigorously evaluated and managed.

In terms of data synthesis, we suggest a focus not just on carbon and nitrogen, but on radiocarbon $\left({ }^{14} \mathrm{C}\right)$ and ${ }^{13} \mathrm{C}$ to estimate turnover times. The use of stable and radioisotopes has greatly expanded over the last decade, providing a literature relevant to the goals listed here. There would be a significant synergy between this and the Ecosystem `effort described above. 


\section{SUPPORTING SCIENCE}

\section{Forest management for sequestration}

Several scholars have provided initial estimates of the potential of forest to sequester carbon. For example, Sedjo, Sohngen, and Mendelsohn (2001) argue that the supply of forest carbon will vary over time and depend on the value of carbon credits. They estimate the year 2000 level of forest carbon to be equal to about $820 \mathrm{Gt}$, and further estimate that an initial price of $\$ 50 /$ ton $\mathrm{CO}_{2}$ over the 21 st century will add another $132 \mathrm{Gt}$ of sequestered carbon. These estimates indicate the large potential, and the challenge is to conduct research leading to policies that will allow realizing this potential. Some of the Clean Development Mechanism projects under the Kyoto protocol pay for forest carbon sequestration in various places (Subak 2002). The payment for forest carbon sequestration can be linked with other programs of payments for environmental services that aim to control deforestation. They include programs like the old debt for forest program and the Mexican and Costa Rican forest preservation programs (Alix-Garcia etal., 2006). However, the design of effective forest carbon sequestration programs requires better quantitative understanding of various tree species under varying conditions, and the changes in forest management practices resulting in response to various payments. Furthermore, few of the existing approaches have considered soil C sequestration, but evidence from tropical forests suggests that there is considerable potential of tropical reforestation projects for long-term soil C sequestration (Silver et al. 2000, 2004; MarinSpiotta et al. 2007, 2008). Research on forest sequestration should also address issues of measurement and attribution and effective program design, recognizing the difficulties of monitoring and enforcement, and the natural and social complexities of forest systems.

Managed forests represent an opportunity for increased carbon sequestration but not without risks. This opportunity includes both below- and aboveground storage, as well as improved life-cycle storage of manufactured forest products. The carbon dynamics of a managed forest therefore involve estimates of carbon sequestration, but also contributions to litter and soil, life cycles of manufactured products and waste, and potential energy production and displaced fossil fuels. At one extreme, fast-growing species such as some eucalyptus or redwood can accumulate biomass and carbon at very rapid rates, and management may be able to increase these levels. These higher-productivity forests may represent the greatest per unit area opportunity for carbon sequestration. However, sites with lower productivity may be more common and also represent better economic opportunities. Finally, many forests are at increased risk of catastrophic fire with increasing aboveground carbon storage, at locations where fires can release massive amounts of stored carbon in short periods of time. For these forests, including many in western North America, carbon storage has to be balanced with fuel accumulations and fire risks.

Research needs involve all aspects of the carbon dynamics of managed forests, including variations in species and site quality, as well as silvicultural strategies for enhancing carbon storage above- and belowground, such as longer rotations, species alternatives, tree density management, and others. Interdisciplinary research with wood product specialists, fire scientists, and social scientists is needed to unravel the potential for manufactured product storage, and manage the risk between catastrophic fire and 
maximizing storage. At present, estimates of carbon in managed forests are derived from general allometric relationships with tree size and general conversions from biomass to carbon. Research is needed to develop precise relationships to estimate carbon in forest components and to understand variations in carbon content of wood and other components in relation to forest management.

\section{Agricultural management for $\mathrm{CO}_{2}$ and non- $\mathrm{CO}_{2}$ greenhouse gas mitigation}

Agricultural development provides yields to satisfy both the dietary demands of an ever-increasing population and some of society's energy needs. Anthropogenic increases in greenhouse gases raise questions about the role of agriculture in mitigating or enhancing $\mathrm{CO}_{2}$ and $\mathrm{N}_{2} \mathrm{O}$ emissions (CAST 2004; Paustian et al., 1998). Typically, conversion of natural lands to agriculture causes a loss of soil organic carbon to the atmosphere. Management techniques focused on conserving soil organic carbon have been studied as a means to minimize or reverse this loss. For example, the conversion of conventional tillage systems to no-till or conservation-till has been shown to result in less carbon loss from agricultural soils in most cases and an increase in soil carbon in others. Such tillage practices, however, may not be ideal in all locations, given the need for equipment, no-till hybrids, and training for producers. Focused research on a number of crop species over a wide geographical distribution could help to identify best management practices to mitigate $\mathrm{CO}_{2}$ emissions while maintaining productivity. There remains a large research need for annual crops, which may present more challenges regarding management relative to perennial crops, grassland, or forested ecosystems, yet represent a significant portion of the greenhouse gases from ongoing land management. Integrated research programs that quantify the best management practices and the sequestration potential of annual crops over a wide geographical distribution could help to identify the potential of agriculture to sequester carbon.

Before agricultural management can be considered a viable mitigation option, comprehensive assessments are needed that consider the net impact of changes in agricultural management and agronomic inputs on atmospheric concentrations of all three major biogenic greenhouse gases (i.e., $\mathrm{CO}_{2}, \mathrm{~N}_{2} \mathrm{O}$, and $\mathrm{CH}_{4}$ ). A focus on $\mathrm{N}_{2} \mathrm{O}$ emissions from agriculture is needed, because $\mathrm{N}_{2} \mathrm{O}$ is the main source of radiative forcing from agricultural management (after land conversion), and there is a great potential to mitigate $\mathrm{N}_{2} \mathrm{O}$ emissions in intensively managed agro-ecosystems. In addition, the biggest difference in radiative forcing among biomass production options for biofuels results from differences in $\mathrm{N}_{2} \mathrm{O}$ emissions. However, the uncertainty around $\mathrm{N}_{2} \mathrm{O}$ emissions from agriculture is the largest of all of the GHGs. Biogeochemical simulation models have matured enough that they can be useful tools to reliably predict $\mathrm{N}_{2} \mathrm{O}$ emissions if they are sufficiently calibrated and validated. Consequently, accurate assessments of $\mathrm{N}_{2} \mathrm{O}$ budgets can be achieved by integrating detailed, event-related $\mathrm{N}_{2} \mathrm{O}$ flux measurements with predictions of daily and seasonal $\mathrm{N}_{2} \mathrm{O}$ emissions by well-validated biogeochemical models.

A comprehensive assessment of the potential for $\mathrm{C}$ sequestration and reduced $\mathrm{N}_{2} \mathrm{O}$ emissions not only needs to consider the technical potential, but also the economic feasibility. Research is needed to determine whether producers can mitigate greenhouse gas fluxes at a cost competitive with alternative approaches. Consequently, the coupling of site-specific ecosystem and economic simulation models is pertinent. We need 
assessments of the biophysical potential and economic feasibility for soil $\mathrm{C}$ sequestration and reduction of trace gas emissions in agricultural soils through the integration of targeted measures, spatial databases on environmental factors, and land-use data with ecosystem simulation models and economic analyses.

\section{Prediction and verification capabilities for policy support}

There is growing recognition that terrestrial carbon sequestration (CS) can play a major role in an effective strategy to address climate change. While it is recognized that the outcomes of specific CS projects are reversible, effective management of these activities will result in a significant aggregate impact on atmospheric greenhouse gas stocks over time. Terrestrial CS is especially valuable in the shorter term, because it can be effective, inexpensive to implement, and help buy time for the development and introduction of alternatives energy sources or energy-conserving technologies. As described above, terrestrial sequestration can also provide other environmental and social benefits.

Prediction. To develop polices that will encourage and reward CS, it is crucial to obtain quantitative knowledge of the human activities and the processes that generate CS, as well as the human behavior that will lead to responses to policy incentive that will result in CS. Development of effective CS polices requires the development of practical and cheap measurement techniques that will attribute CS to the responsible agents. Finally, the design of effective incentive and other policy schemes that combine knowledge of physical and behavioral relationships is another research challenge essential to making BECS an effective element of GHG control policy.

Verification and Certification. The workshop did not identify any basic research needs in this area as high priority. However, developing applications for practicable measurement and verification strategies is a high priority, as is developing protocols for creating certification for practices so that certification can replace the need for on-site measurement of economic $\mathrm{C}$ sequestration benefits.

\section{Integrated Assessment}

Understanding the consequences of land cover and land-use change and management practices, including terrestrial carbon sequestration, requires combining knowledge of the biophysical sciences with dynamics of socio-economic systems, including interactions of land-use dynamics with climate change and variability. While significant research has focused on biophysical and socio-economic drivers of land management, an integrated assessment (IA) that links these factors is needed to quantify the feedbacks and responses between these factors (Antle et al., 2001). In addition, IA can help evaluate and avoid unintended environmental or socio-economic consequences of terrestrial sequestration, such as the potential for increased soil carbon stocks to cause larger $\mathrm{N}_{2} \mathrm{O}$ emissions, or for sequestration markets to change economic pressures on lands used for subsistence agriculture.

The IA explores the magnitude and the kinds of benefits, risks, and incentives required to achieve greater $\mathrm{C}$ sequestration in managed terrestrial systems. Ongoing assessment activities are tightly linked to and modified according to new knowledge and insights from the field and laboratory studies. Similarly, results from the assessment can 
provide guidance for the scientific program in focusing on parameters that could realistically be manipulated or that influence adoption of alternative land-management practices. The overall assessment approach comprises five discrete analyses that bear on the environmental and economic outcomes of enhanced terrestrial $\mathrm{C}$ sequestration. Together these highlight opportunities for net reductions in greenhouse gas emissions and the costs (or ancillary benefits) of achieving them.

$>$ Scientific understanding of carbon sequestration mechanisms in terrestrial ecosystems. The goal is to develop science-based methods for producing a national inventory of terrestrial ecosystem carbon sequestration potential that is spatially explicit. This goal can be accomplished by summarizing process understanding and geographical information to produce high quality, spatially explicit assessments of national terrestrial ecosystem $\mathrm{C}$ sequestration potential under different management practices, such as crop rotation, tillage intensity, and land management.

$>$ Source data. The goal is to collect a number of data sources to measure, model, and predict changes in soil carbon flux. To obtain soil carbon flux estimates with high spatial resolution and that cover a large geographical region, data are particularly needed that (i) represent local- to field-scale carbon dynamics, (ii) are consistently collected across a region of earth, and (iii) enable the attribution and distribution of carbon dynamics to appropriate land-use classes across the region. Data that meet these requirements are, respectively, in situ field measurements, national inventory data, and remote sensing products.

$>$ Net impact on greenhouse gas emissions. The goal is to evaluate the actual net effects of practices that enhance carbon sequestration in soils on global warming potential, by taking into account the carbon costs (fertilizer, machinery operation) and $\mathrm{N}_{2} \mathrm{O}$, NOx, and $\mathrm{CH}_{4}$ emissions associated with those practices. A key question is whether fuel and fertilizer inputs required to increase aboveground and belowground $\mathrm{C}$ stocks result in greater $\mathrm{C}$ emissions to the atmosphere than carbon sequestration, or will savings of fuel and fertilizer amplify the greenhouse benefits?

$>$ Balance of environmental impacts and benefits. The goal is to improve our understanding of the environmental impacts and benefits of carbon sequestration in terrestrial ecosystems and create improved tools for prediction of impacts. A key question to be addressed is whether practices that increase soil $\mathrm{C}$ sequestration-such as increased application of $\mathrm{N}$ fertilizer or other chemicals on no-till fields-also increase water pollution?

$>$ Economic analyses of soil carbon sequestration. The goal is to understand the economic and social impacts of carbon sequestration in terrestrial ecosystems, especially the pressures it may create on land use and production in the agricultural and forest sectors. A key question to be answered is what dollar value for sequestered $\mathrm{C}$ would be sufficient to change land-management practices such that additional $\mathrm{C}$ is sequestered? 


\section{Geologic Carbon Sequestration}

\section{Foreword}

Concern about safety. Progress in implementing geologic carbon sequestration (GCS) on the scale needed to make an impact on global climate is hampered by concerns about safety and effectiveness. The main questions center on whether $\mathrm{CO}_{2}$ will migrate away from the intended storage formation and leak out of the ground, with potential impacts on health, safety, and the environment, as well sequestration effectiveness. While geologic storage sites will be chosen for their ability to contain buoyant supercritical $\mathrm{CO}_{2}$ by one or more trapping mechanisms, the enormous volumes of $\mathrm{CO}_{2}$ that need to be injected will tend to cause injected $\mathrm{CO}_{2}$ to permeate large regions over which discontinuities in caprock sealing formations may be present.

Accelerate trapping, block conduits. GCS as currently envisioned relies on four primary trapping mechanisms to sequester $\mathrm{CO}_{2}$ indefinitely in the subsurface: (1) stratigraphic trapping; (2) solubility trapping; (3) residual phase trapping; and (4) mineral trapping (IPCC, 2005). Over time, $\mathrm{CO}_{2}$ is expected to become more securely trapped as it dissolves into saline formation waters and becomes incorporated into mineral phases as shown in Figure 4. One way to improve $\mathrm{CO}_{2}$ storage security is to decrease the amount of time that $\mathrm{CO}_{2}$ remains as a separate buoyant supercritical phase, while a second way is to block potential conduits for $\mathrm{CO}_{2}$ migration.

\section{BIOLOGICAL ENHANCEMENTS FOR GCS}

\section{Mitigation of well leakage and well cement degradation}

\section{Background}

Wells have been drilled extensively for hydrocarbon exploration and production in many of the same geological environments, sedimentary basins in particular, that are considered favorable for GCS. Furthermore, well density (as shown in Figure 5) tends to be high in the same areas that have large $\mathrm{CO}_{2}$ sources such as in the U.S. and Canada. Because of the large expected $\mathrm{CO}_{2}$ plumes associated with GCS, wells are considered the primary potential leakage pathway for $\mathrm{CO}_{2}$ stored in the deep subsurface (Gasda et al., 2004; Celia et al., 2004; IPCC, 2005). Well construction involves bonding the metal casing to the formation using well cement, and plugging the well over part or all of its length with cement prior to abandonment. When well cement comes into contact with high concentrations of $\mathrm{CO}_{2}$ dissolved in water, there are potentially significant reactions that can degrade the bonding and plugging properties of the cement.

The main products formed by the (Portland) cement hydration process are calciumsilicate-hydrate (C-S-H) and calcium hydroxide $(\mathrm{Ca}(\mathrm{OH}) 2(\mathrm{~s})$ ) (Kutchko et al., 2007). C-S$\mathrm{H}$ is gel-like, semi-amorphous, contains approximately $70 \%$ of the hydrated cement, and is the primary binding material. $\mathrm{Ca}(\mathrm{OH}) 2$ (s) deposits, which typically comprise roughly $15 \%$ to $20 \%$ of the cement, nucleate in available pore space during early hydration and grow rapidly to occupy available space between cement grains and early $\mathrm{C}-\mathrm{S}-\mathrm{H}$ deposits 
(e.g., Kutchko et al., 2007). The well-bore cement can be altered by geomechanical and geochemical processes. Expansion or contraction of the innermost casing due to pressure testing, $\mathrm{CO}_{2}$ injection, or hydrocarbon production can degrade cement, especially within the annulus due to the narrowness of this region. Cement degradation (carbonation) by carbonic acid created during injection of $\mathrm{CO}_{2}$ may turn existing wells into highpermeability pathways for $\mathrm{CO}_{2}$ leaks. On the one hand, the release of calcium may lead to the formation of calcium carbonate; on the other hand, calcium depletion within casing-bond and bridging cement and dissolution of its hydrates may lead to the formation of a high-permeability silica gel layer with poor mechanical integrity. For these reasons, both decades-old abandoned wells and modern $\mathrm{CO}_{2}$ injection wells are considered the primary potential conduits for leakage. The ability to prevent well leakage and to mitigate leaking wells is critically important for improving GCS storage security.

\section{Idea and Objective}

The objective of this research area is to use engineered biofilms to reduce pore space and permeability, encourage plugging of pores and fractures in well cement, and (particularly) heal any breaches in the seal between casing and formation. The technology of using engineered biofilms to plug free pore space - thereby substantially reducing porosity and permeability - has been proven at the 10-meter scale in shallow subsurface field tests (Cunningham, et al., 2003). Recent experiments show that engineered biofilms grown at 82 bar $(1200 \mathrm{psi})$ and $35^{\circ} \mathrm{C}\left(95^{\circ} \mathrm{F}\right)$ can reduce permeability in rock cores and withstand short-term challenges by supercritical carbon dioxide $\left(\mathrm{scCO}_{2}\right)(\mathrm{Cunningham}$ et al., 2005). Additional experiments show promise that it may be possible to engineer biofilm barriers that simultaneously precipitate minerals (e.g., biomineralization of calcium carbonate), thereby providing long-term sealing of preferential leakage pathways. Successful development of these biologically based concepts will result in a $\mathrm{CO}_{2}$ leakage mitigation technology that can be applied either before $\mathrm{CO}_{2}$ injection or as a remedial measure.

\section{Research Approach}

The research approach needs to focus in the short term (2-3 years) on laboratory experiments that examine biofilms in rock cores and degraded well cement samples (e.g., from $\mathrm{CO}_{2}$ enhanced oil recovery [EOR] wells) under relevant reservoir conditions (e.g., $75-95$ bar [1100-1400 psi] and $35-60^{\circ} \mathrm{C}$ [95-140 $\left.\mathrm{F}\right]$ ). These experiments will examine the sealing capability, durability, and longevity of biofilm and biomineralization approaches. Follow-on research can be directed at developing biofilms within degraded well cement in new experimental wells (e.g., within the Deep Underground Science and Engineering Laboratory (DUSEL), or existing wells in an oil field.

In addition to biofilm studies, investigation of biomineralization processes that either prevent well cement from being degraded or that can repair degraded well cement are required. This approach is discussed within the context of the broader topic of microbial interactions with mineral surfaces (below). 


\section{Resources Needed}

An effective laboratory-based research plan would require approximately $\$ 300 \mathrm{k} / \mathrm{yr}$ for $2-$ 3 years. Given that this research will build upon over 10 years of previous, successful biofilm barrier research performed by the Center for Biofilm Engineering at Montana State University, the likelihood of achieving a successful outcome for application in the deep subsurface is considered very good.

\section{Materiality}

Because wells have been identified as the main potential leakage pathway from the deep subsurface to the atmosphere, and because potential leakage remains a primary concern from the standpoint of both GCS effectiveness and health, safety, and environmental (HSE) impact, a demonstration of the ability to solve the well-leakage problem, through either a biofilm leakage mitigation or pre-treatment process, could close the door on this concern. With the well-leakage issue diminished in importance, large sedimentary basins in North America that have been exploited for oil and gas resources, and correspondingly penetrated by vast numbers of exploration and production wells, could be used safely for large-scale deployment of GCS. Considering storage capacity to come only from depleted oil and gas reservoirs worldwide for which well-leakage is a concern, the potential materiality of overcoming the well-leakage concern by biological approaches makes available $675 \mathrm{Gt}$ of $\mathrm{CO}_{2}$ sequestration capacity as shown in Figure 6 (IPCC, 2005).

\section{Microbial interactions with mineral surfaces}

\section{Background}

$\mathrm{CO}_{2}$ injections into deep subsurface formations for GCS will encounter largely stable biogeochemical systems that have developed over geological time. While the details of the impacts that $\mathrm{CO}_{2}$ injection will impart on these biogeochemical systems are largely unknown, certain aspects of abiotic geochemistry_-such as $\mathrm{pH}$ reduction, mineral dissolution, and mobilization of cations - can be confidently predicted. The opportunity exists to exploit the known effects of $\mathrm{CO}_{2}$ injection to enhance biologically mediated mineral trapping and thereby increase GCS storage security.

\section{Idea and Objective}

Microbial consortia (in the context here, bacteria) play a role in weathering and diagenesis processes by breaking down various minerals into chemical elements that are important to their biochemistry and that can induce the precipitation of carbonate minerals. It may be possible to harness these natural biologically mediated processes to enhance the release of cations that occurs when $\mathrm{CO}_{2}$ in groundwater partially dissolves minerals and coatings, thereby imparting the alkalinity (specifically $\mathrm{HCO}_{3}{ }^{-}$and $\mathrm{CO}_{3}{ }^{2-}$ ) necessary for the uptake of $\mathrm{CO}_{2}$ and its fixation as a precipitated carbonate mineral (e.g., $\mathrm{Xu}$ et al., 2005). This process could be used to accelerate mineral trapping. If applicable at a large scale, this may provide the means to enhance sealing across the geochemical fringe zone of a $\mathrm{CO}_{2}$ storage reservoir, and possibly promote mineral trapping. A promising application is the sealing of leaking wells at a local scale. To make progress in 
this area, the biogeochemical interactions between bacteria and mineral surfaces at reservoir conditions need to be investigated.

\section{Research Approach}

Ideally, experiments would be conducted with characterized bacterial communities and rock samples collected from a saline aquifer anticipated to be used for GCS. Using laboratory batch and flow-through reactors capable of maintaining representative reservoir pressures and temperatures, we will analyze core samples and fluids before and after long-term exposure to $\mathrm{CO}_{2}$-charged waters. Experiments will be designed to answer such questions as:

- What is the effect of $\mathrm{pCO}_{2}$ on bacterial viability, community, and interaction with mineral surfaces?

- Given a rock texture, mineralogy, and fluid, can bacterial interaction be predicted?

- How do capable bacterial species catalyze the precipitation of carbonate minerals?

- What are the rates of bacterial release of cations and the accompanying rates of $(\mathrm{Ca}$, $\mathrm{Mg}, \mathrm{Fe}$ ) carbonate precipitation? What determines these rates?

-What is the best material for stimulating bacteria for mineral interaction?

\section{Resources Needed}

These fundamental experiments require apparatuses for the incubation of batch or flowthrough column experiments at pressures and temperatures of interest, with controlled geochemical conditions (e.g., $\mathrm{pCO}_{2}, \mathrm{pO}_{2}, \mathrm{pH}$ ) and access for biogeochemical monitoring/sampling and post experiment analysis. Analytical facilities needed for geochemical, isotopic, mineral surface/bacterial imaging, and bacterial DNA analyses include quad-ICPMS, ALS (Advanced Light Source), and PhyloChip, all available at LBNL. This research is feasible and is likely to produce useful results in a relatively short period of time ( $\sim 3$ years) by a team of $2-4$ researchers.

\section{Materiality}

The significance of enhancing the rate at which the primary sequestration process transitions from stratigraphic trapping to mineral trapping cannot be overemphasized. Simply put, if mankind could transform $\mathrm{CO}_{2}$ emissions into carbonate rocks, such rocks could be stored at the earth's surface and would represent a form of $\mathrm{CO}_{2}$ sequestration stable over geologic time scales. Recognizing the difficulty of achieving this transformation quickly enough to undertake above ground, the next-best environment is in the deep subsurface, where the $\mathrm{CO}_{2}$ will remain trapped until the necessary precipitation reactions occur. The time frame over which $\mathrm{CO}_{2}$ is mobile under current understanding of GCS can be thousands of years or more. If this time period could be reduced to hundreds of years, concerns about $\mathrm{CO}_{2}$ storage integrity would diminish drastically, making permitting of GCS sites and certifying carbon storage credits a routine matter and potentially opening up storage opportunities and projects across the globe. Furthermore, the ability to increase the rate of mineral trapping could allow local GCS (e.g., beneath existing power plants) in reservoirs without ideal stratigraphic trapping capacity, thus obviating the need for long pipelines from existing power plants. 
Referring to Figure 6, which shows the IPCC's estimate of worldwide saline formation storage capacity of at least $1000 \mathrm{Gt} \mathrm{CO}_{2}$ (IPCC, 2005), we judge the materiality of biological enhancements to mineral carbonation as very high.

\section{Enzymatic approaches}

\section{Background}

Reaction of $\mathrm{CO}_{2}$ with a cationic species to form a stable compound, such as calcium carbonate, offers safe long-term sequestration: carbonate minerals constitute the earth's largest single $\mathrm{CO}_{2}$ repository, estimated to contain an amount of carbon equivalent to $150,000 \times 10^{12}$ tonnes $\mathrm{CO}_{2}$ (Wright and Colling, 1995). Natural processes that form $\mathrm{CaCO}_{3}$ are well known. Extending these to deal with the very large scale of emissions and short time frame required to capture and sequester the $\mathrm{CO}_{2}$ emitted by large coalfired boilers poses some engineering challenges, but biological enhancement of the process is possible (Dunsmore, 1992; Bond et al., 2001a). Accelerated carbonate formation also offers the possibility of immediate benefits as a tool in the treatment of well-bore leakage.

\section{Idea and Objective}

A biomimetic process has been developed, in which the enzyme carbonic anhydrase (CA) is used to accelerate an aqueous processing route to carbonate formation. Feasibility of the approach has been demonstrated (Bond et al., 1999, 2001a). Bacterial overexpression has been shown to afford the possibility of economic enzyme production, and viable means of enzyme immobilization have been developed. Tests to date suggest that the enzyme will perform well in actual service conditions (Bond et al., 2001b; Simsek-Ege et al., 2002 a, b). Counterions for carbonate formation may be supplied from a variety of sources, such as produced waters from the oil and gas industry, or seawater (Abel, 2007; Bond et al., 2004, 2005; Liu et al., 2005; Stringer and Bond, 2007). Feasibility of the approach has been demonstrated at both bench and laboratory scale, with the use of a commercial buffer. The objective now is two-fold:

1. To identify the optimum buffering system for economic $\mathrm{pH}$ control.

2. To apply this biomimetic process to rapid carbonate formation from aqueous solution for rapid remediation of well-bore leakage.

\section{Research Approach}

Many of the engineering hurdles for biomimetic sequestration have been overcome, while $\mathrm{pH}$ control remains a challenge. Possible economic buffering routes include the use of industrial or agricultural waste products such as alkaline fly ash, ammonia, and urea. Another possibility is the use of microorganisms to modify $\mathrm{pH}$. An experimental program is needed to study $\mathrm{pH}$ control, including microbial approaches.

\section{Resources Needed}

Two-months per year PI support and full-time post-doc for three years $(\sim \$ 120 \mathrm{k} / \mathrm{yr})$, along with use of laboratory equipment (spectrometers for chemical analysis, SEM and XRD for product determination, etc.) and travel to meetings, for a total of $\$ 200 \mathrm{k} / \mathrm{yr}$ for three years. 


\section{Materiality}

1. Biomimetically accelerated carbonate formation in buffered aqueous solution could prove very valuable in the treatment of leakage associated with, for example, failed well-bore casings. Combined buffering and enzyme use offer the potential for rapid conversion of leaking $\mathrm{CO}_{2}$ to stable carbonates at more modestly basic $\mathrm{pH}$ than would be necessary with the use of buffered brines alone, thus minimizing additional environmental impact from the remediation process. If the concern over well-bore leakage can be alleviated, many of the very mature depleted oil and gas reservoirs that are penetrated by numerous wells abandoned decades ago could be made available for $\mathrm{CO}_{2}$ storage.

2. Development of the process for large-scale, long-term implementation at power plants (as distinct from rapid remediation of localized leaks) would afford an alternative approach to long-term sequestration without concerns about leakage and the associated issues of licensing, monitoring, etc. This would be a particularly attractive approach for power plants located near to sources of waste brines that could be used to provide the necessary cations. In the Permian Basin, for example, produced waters from the oil and gas industry could provide the necessary cations for sequestration of $\sim 57 \%$ of that region's $\mathrm{CO}_{2}$ production from electricity generation.

\section{CRitical Supporting Science for Biologically EnHANCEd GCS}

\section{Microbial Community Structure and Function}

\section{Background}

A fundamental understanding of microbial community structure and function, and its linkage to the biogeochemistry of deep saline formations, is critical to our ability to develop biological enhancements for GCS. Although initial studies aimed at determining microbiological characteristics of deep saline formations have been undertaken (e.g., Onstott, 2004), we know very little about microbial community structure and function in deep saline environments, despite the fact that these environments provide the majority of $\mathrm{CO}_{2}$ storage capacity (IPCC, 2005; Lin et al., 2006).

\section{Idea and Objectives}

The objective of research in this area is to characterize the microbial community in detail in one or two deep saline formations that are under consideration for GCS.

\section{Research Approach}

Systems biology capabilities that combine a variety of molecular techniques for directly examining microbial community structure and function need to be combined with molecular techniques to understand the biogeochemistry of the saline formations. This will involve direct analysis of DNA, RNA, proteins, stable isotope ratios, gene expression, salinity, stress responses, functional gene changes, and any hydrocarbons that may be present. These saline, thermal, and carbon-limited environments are expected to be extreme, with a relatively low-diversity microbial community. Thus, even 
unculturable species can be rapidly identified and activities determined using metagenomics, metatranscriptomics, and proteomics. This will further enable determination of stress responses (see below), dominant metabolic pathways, functional activity, and the overarching processes controlling the biogeochemistry in these environments.

\section{Resources Needed}

This work requires sophisticated microbiological tools such as those available in the laboratories of UCB, LBNL, and UIUC. With a small team of researchers numbering 3-4 people, significant progress could be made in this area in 2-3 years.

\section{Microbial Survivability and Stress Response}

\section{Background}

Essential to the application of biological enhancements of GCS is an understanding of the impacts of $\mathrm{CO}_{2}$ injection on microbes at depth. Whether the goal is to enhance existing microbial processes or introduce new ones, the response of microbes to exposure to $\mathrm{scCO}_{2}$, with and without contaminants that might be present (e.g., $\mathrm{SO}_{\mathrm{x}}$ and $\mathrm{NO}_{\mathrm{X}}, \mathrm{H}_{2} \mathrm{~S}$ ) and $\mathrm{CO}_{2}$-rich brines must be understood and verified for the expected enhancement to be successful. This issue is closely related to the microbial community function work, except that it focuses on the impacts of injection rather than the natural ambient system. In short, understanding the biogeochemical environment and the impacts of $\mathrm{CO}_{2}$ injection on this environment are essential in order to develop ways of enhancing GCS storage security.

\section{Idea and Objective}

The objective of work in this area is to evaluate the impact of anthropogenic combustion waste streams consisting primarily of $\mathrm{CO}_{2}$ on microbes encountered during GCS at in situ reservoir conditions. Study of the stress-response relationships will allow identification of robust microbes able to survive and possibly thrive under $\mathrm{CO}_{2}$ injection, while producing a tangible enhancement to GCS, for example by increasing the rate of mineral trapping, or rates of dissolution and formation of bicarbonate.

\section{Research Approach}

Laboratory experiments of various bacteria in biofilms exposed to $\mathrm{scCO}_{2}$ and $\mathrm{CO}_{2}$-rich brine will be carried out at in situ reservoir conditions. Flow-through and batch reactors will be employed. Following exposure to fluids, samples will be analyzed for total and viable cells and their spatial distribution. Extracellular polymeric substances (EPS) on the outside of biofilms can offer a protective shield to $\mathrm{CO}_{2}$ by virtue of large surface area and number of functional groups for interaction and immobilization of $\mathrm{CO}_{2}$ (Mitchell et al., submitted 2007). The first phase would focus on $\mathrm{CO}_{2}$; later phases will include contaminants expected to be present in the flue gas, including $\mathrm{SO}_{\mathrm{x}}, \mathrm{NO}_{\mathrm{x}}$, and $\mathrm{H}_{2} \mathrm{~S}$.

Key culturable organisms should be selected for additional extremophile characterization using the systems biology pipeline like those developed in the Virtual Institute for Microbial Stress and Survival (VIMSS) to rapidly bring such organisms to the level of a model organism. Practical applications may include predictive models of the stability and environmental risks of GCS over thousands of years, and tools (microarrays, real time 
PCR primer sets) for assessing microbial changes that could provide indications of biogeochemical changes relevant to long-term management.

\section{Resources Needed}

The laboratory setup described in numerous places here consisting of batch and flowthrough reactors capable of maintaining representative reservoir pressure and temperature, along with associated sampling and analysis equipment are needed for this effort. In addition, microbiological analytical tools will be needed. This effort carried out in conjunction with the microbial community and function research could be accomplished over 2-3 years by $2-3$ researchers.

\section{Microbial Transport}

\section{Background}

Transport of biological agents or nutrients within the reservoir may be a key element of activities related to biological enhancement of GCS. Enhancements involving well leakage and microbe-mineral interactions potentially involve the need to inject microbial inocula into the storage formation, transport the injected cells over length scales of 10 to 100 meters, and also control the distribution of injected cells along the flow path. This supporting research topic is therefore of general importance to BECS activities.

\section{Idea and Objective}

Previous research on starvation-enhanced microbial transport shows that bacteria starved for 3-6 weeks shrink in size, become metabolically inactive, and greatly decrease their affinity to stick to solid surfaces. These characteristics greatly improved their transportability through porous media columns of up to $20 \mathrm{~m}$ in length. The feasibility of achieving similar results in rock cores under reservoir conditions appears to be high. Controlling fluid flow in situ remains an outstanding engineering challenge, although simple pumping dipole arrangements are a first-order approach.

\section{Research Approach}

Research on starvation-facilitated transport of microbes in soils and near surface aquifers has been done previously (Cunningham et al., 2007). Similar studies can be done using rock cores under pressures and temperatures typical of geologic sequestration environments - 76-97 bar (1100-1400 psi) and 35-60 ${ }^{\circ} \mathrm{C}\left(95-140^{\circ} \mathrm{F}\right)$. Core segments arranged in series will be used to develop length scales of several meters. Starved bacterial inocula will be injected and their distribution along the flow path monitored by recently developed Magnetic Resonance Microscopy techniques. These experiments can be done as part of the well-cement biofilm leakage mitigation research.

\section{Resources Needed}

The laboratory-based research plan described above, if performed at the Center for Biofilm Engineering, Montana State University, will include use of the same temperature controlled, high pressure core test system useful in well-leakage and mineral-microbe surface studies. This work can be carried out in parallel with biofilm stress studies with 3-5 people. 


\section{Geophysical Monitoring}

\section{Background}

A crucial component of any effort to biologically enhance subsurface $\mathrm{CO}_{2}$ sequestration is a strategy for monitoring the relevant microbial processes and geochemical perturbations; such data are required to validate the basic enhancement process, verify changes in carbon state (e.g., mineral trapping), and to optimize the treatment process. Without a comprehensive monitoring system in place, the complex interactions between changes in nutrient availability, naturally occurring microbial communities, and the injected $\mathrm{CO}_{2}$ volume cannot be quantified, much less understood.

\section{Idea and Objective}

The first step in the monitoring process is to establish a baseline state from which subsequent changes can be referenced. Repeat measurements are made with a periodicity designed to capture the most important transitions in the system. In cases where this timescale is small and repeated deployments are prohibitively expensive, the installation of permanent sensor arrays becomes a viable option. Characterization and monitoring of the active microbial population requires access to minimally altered fluid samples from the reservoir unit. Most relevant geochemical parameters can be extracted from the same samples; fluid sampling techniques designed to preserve $\mathrm{P} / \mathrm{T}$ state such as U-tube sampling (Freifeld et al., 2005) are essential. Since changes in chemical or biological activity are difficult to directly measure at the reservoir scale, effective monitoring requires a way to infer these alterations from remote measurements. Seismic imaging techniques, if properly deployed, hold the potential to map these changes beyond the borehole, the main limitation being the sensitivity of rock elastic properties to biogeochemical perturbations. If the relationship between biologically induced mineral trapping could be related to seismic response, then mapping the volumetric extent of alteration, and possibly estimating the fraction of $\mathrm{CO}_{2}$ sequestered in a mineral phase, becomes feasible.

\section{Research Approach}

Whereas geophysical imaging is intrinsically linked to field-scale procedures, the interpretation of monitoring data demands a more controlled environment; many of the interactions between biology, geochemistry, hydrogeology, and geophysics will only be understood when the complete system is analyzed, e.g., in a laboratory. We advocate the development of an integrated laboratory test-bed for simultaneous measurement of all of the parameters crucial for understanding BECS at in situ temperature and pressure conditions. Such an environment would allow exploration of the basic science underpinning not only monitoring, but the entire subsurface BECS strategy.

\section{Resources Needed}

Historically, projects of this type have been stymied by boundaries between disciplines, particularly differences in scientific priorities for both researchers and funding agencies. Here, synergy between research areas involving flow-through and batch reactors can be achieved to reduce costs, with savings used to deploy next-generation components in the 
test-bed such as high-resolution CT scanning capabilities. This effort could be carried out by $2-3$ people over a period of $2-3$ years.

\section{Modeling and Prediction}

\section{Background}

Numerical simulation of subsurface reservoir fluid production and injection, along with groundwater flow are relatively mature and established fields used in the extractive industries and groundwater resource management. Modeling situations in which contaminants are transported and involved in biogeochemical reactions is a nascent field in rapid ascendancy, due to its importance in a wide variety of natural (e.g., nitrogen and carbon cycling in soils) and engineered systems (GCS systems).

\section{Idea and Objective}

To advance biological enhancements to GCS, research is needed to develop coupled biogeochemical reaction networks that can be modeled to predict chemical changes in the formation waters, as well as reactions involving minerals, coatings, and cements, along with biological effects. Coupled processes on multiple scales including multiphase flow and geomechanical effects may be critical to developing a predictive capability.

\section{Research Approach}

The approach to this task is to build upon existing frameworks, e.g., the TOUGH2 framework (Pruess et al., 1999), and add microbial processes to the reactive geochemical system. This is being done in another project in the context of soil nitrogen cycling (e.g., Maggi et al., 2008), and there is no reason it cannot be done for high pressure and temperature also. Tools like the reactive chemical transport simulator TOUGHREACT (e.g., Xu et al., 2005) should be used to link community structure, population dynamics, functional groups, stress response pathways, and specific metabolic flux dynamics to geochemical fluxes, chemical interactions with the fluids, and physical transport akin to colloids in the aqueous phase. The mathematical model development should initially be guided by models of microbial interactions and kinetics published in the literature, and will subsequently be refined as data and process models from field sampling and bioinformatics efforts become available. The goal should be to create a numerical laboratory that will allow a systematic study of factors affecting microbial activity, such as composition of aqueous and gas phases, availability of nutrients, and mineral substrates. Multiscale modeling from pore level to field scale will be needed, which will require flexible, adaptive techniques for treating coupled processes playing out in irregular geometric settings.

\section{Resources Needed}

The development of computational tools for BECS can be accomplished by 2-3 people. The time period for developmental work is constrained by progress made in other tasks. In particular, input on reaction networks, phenomenological behavior, and characterization all need to be obtained for model development to proceed. Therefore, work would be carried out starting 6 months to a year later than other tasks, and continue at varying levels of intensity as controlled by interpreted results produced by the other tasks. 


\section{Acknowledgments}

This work was made possible by the Energy Biosciences Institute (EBI) through its financial support of the BECS Workshop, and by the Ernest Orlando Lawrence Berkeley National Laboratory, managed for the U.S. Department of Energy under Contract No. DE-AC02-05CH11231. Guidance on the workshop was provided by Paul Willems and Susan Jenkins (EBI). We thank Dan Hawkes (LBNL) for suggestions to improve the presentation of this report.

\section{References}

Abel, A. (2007). M.S. thesis, New Mexico Tech.

Alix-Garcia, J., A. de Janvry and E. Sadoulet (2006). The role of deforestation risk and calibrated compensation in designing payments for environmental services. In press: Environment and Development Economics.

Amonette, J. E., Jungbae Kim, C. K. Russell, A. V. Palumbo, and W. L. Daniels (2003). Enhancement of soil carbon sequestration by amendment with fly ash. Paper \#47 in: Proceedings of the 2003 International Ash Utilization Symposium, October 2022, 2003, Lexington, KY.

Antle, J., S. Capalbo, S. Mooney, E.T. Elliott, and K. Paustian (2001). Economic analysis of agricultural soil carbon sequestration: An integrated assessment approach. Journal of Agricultural and Resource Economics 26:344-367.

Baisden, W.T., and R.L. Parfitt (2007). Bomb ${ }^{14} \mathrm{C}$ enrichment indicates decadal pool in deep soil. Biogeochemistry 85:59-68.

Baisden, W.T., R. Amundson, and D.L. Brenner (2002). A multi-isotope C and N modeling analysis of soil organic matter turnover and transport as a function of soil depth in a California annual grassland soil chronosequence. Global Biogeochemical Cycles 16:82-1-82-26.

Batjes, N.H., 1996. Total carbon and nitrogen in the soils of the world. European Journal of Soil Science, 47(2): 151-163.

Bond, G.M., G. Egeland, D.K. Brandvold, M.G. Medina, F.A. Simsek and J. Stringer (1999). Enzymatic catalysis and $\mathrm{CO}_{2}$ sequestration. World Resource Review 11: 603-619.

Bond, G.M., J. Stringer, D.K. Brandvold, F.A. Simsek, M-G. Medina and G. Egeland (2001a). Development of integrated system for biomimetic $\mathrm{CO}_{2}$ sequestration using the enzyme carbonic anhydrase. Energy and Fuels 15: 309-316.

Bond, G.M., M-G. Medina, and J. Stringer (2001b). A biomimetic $\mathrm{CO}_{2}$ scrubber for safe and permanent $\mathrm{CO}_{2}$ sequestration. Eighteenth Annual International Pittsburgh Coal Conference Proceedings (December 3-7, 2001, Newcastle, NSW, Australia).

Bond, G.M., N. Liu, A. Abel, B.J. McPherson and J. Stringer (2004). Early results from a laboratory-scale pilot-plant demonstration of enzyme-catalyzed $\mathrm{CO}_{2}$ sequestration with produced waters as cation source. Proceedings of the Seventh International 
Conference on Greenhouse Gas Control Technologies (GHGT-7), (September 5-9, 2004, Vancouver, Canada).

Bond, G.M., S. Date, N. Liu, T. Dunn, T. Villanova, C. Hockensmith, J, Stringer and B.J. McPherson (2005). Effective use of brines for biomimetic $\mathrm{CO}_{2}$ sequestration. 4th Annual Carbon Capture and Sequestration Proceedings; ExchangeMonitor Publications 2005; Washington DC; WWWcarbonsq.com.

Bos, R., H.C. van der Mei, and H.J. Busscher (1999). Physico-chemistry of initial microbial adhesive interactions - its mechanisms and methods for study. FEMS Microbiology Reviews 23:179-229.

Bruun, S., B.T. Christensen, I.K. Thomsen, E.S. Jensen, and L.S. Jensen (2007). Modeling vertical movement of organic matter in a soil incubated for 41 years with ${ }^{14} \mathrm{C}$ labeled straw. Soil Biology \& Biochemistry 39:368-371.

CAST Report No. 141 (2004). Climate change and greenhouse gas mitigation: Challenges and opportunities for agriculture. Keith Paustian, and Dr. Bruce A. Babcock, studies chair, Ames, Iowa, May 2004,141 pp.

Celia, M.A., S. Bachu, J.M. Nordbotten, S.E. Gasda, and H.K. Dahle (2004). Quantitative estimation of $\mathrm{CO}_{2}$ leakage from geological storage: Analytical models, numerical models, and data needs, M. Wilson, T. Morris, J. Gale, and K. Thambimuthu, eds., $7^{\text {th }}$ International Conference on Greenhous Gas Control Technologies, September 5-9, 2004, Vancouver, Canada.

Cheng, W. and A. Gershenson (2007). Carbon fluxes in the rhizosphere. Pages 31-56 in Z. Cardon and J. Whitbeck, editors. The Rhizosphere: An Ecological Perspective. Academic Press, Inc., San Diego.

Chenu, C., and G. Stotzky (2002). Interactions between Microorganisms and Soil Particles: An Overview, In P. M. Huang, et al., eds. Interactions between Soil Particles and Microorganisms. John Wiley \& Sons.

Cunningham A B., R. Gerlach, A. Phillips, and L. Spangler (2005). Microbially enhanced geologic sequestration of supercritical CO2, Proceedings: USDOE Fourth Annual Conference on Carbon Capture and Sequestration, May 2-5, 2005, Hilton Alexandria Mark Center. Alexandria, Virginia..

Cunningham, A.B, R. R. Sharp, R. Hiebert and G. James (2003). Subsurface biofilm barriers for the containment and remediation of contaminated groundwater. Bioremediation Journal 7(3/4): 151-164.

Cunningham, A.B., R.S. Sharp, F. Caccavo Jr., and R. Gerlach (2007). Effects of starvation on bacterial transport through porous media. Adv. Water Resour. 30: $1583-1592$.

Dufrene, Y.F., C.J.P. Boonaert, and P.G. Rouxhet (1996). Adhesion of Azospirillum brasilense: role of proteins at the cell-support interface. Colloids and Surfaces B: Biointerfaces 7:113-128. 
Dunsmore, H.E. (1992). A geological perspective on global warming and the possibility of carbon dioxide removal as calcium carbonate mineral. Energy Conversion Management 33: 565-572.

Edmonds, J., J. Clarke, et al. (2004). Stabilization of $\mathrm{CO}_{2}$ in a B2 world: Insights on the roles of carbon capture and disposal, hydrogen, and transportation technologies. Energy Economics 26(4): 517-537.

FAO, 2005. Global forest resources assessment (2005). Progress towards sustainable forest management. Forestry Paper 147. Rome.

Fierer, N., J. L. Morse, S. T. Berthrong, E. S. Bernhardt, and R. B. Jackson (2007). Environmental controls on the landscape-scale biogeography of stream bacterial communities. Ecology 88:2162-2173.

Freifeld, B.M., R.C. Trautz, Y.K. Kharaka, T.J. Phelps, L.R. Myer, S.D. Hovorka, and D.J. Collins (2005). The U-Tube: A novel system for acquiring borehole fluid samples from a deep geologic $\mathrm{CO}_{2}$ sequestration experiment. Journal of Geophysical Research-Solid Earth, 110 B10203.

Gasda, S.E., S. Bachu, and M.A. Celia (2004). The potential for $\mathrm{CO}_{2}$ leakage from storage sites in geological media: Analysis of well distribution in mature sedimentary basins. Environmental Geology 46: 707-720.

Gill, R.A., and I.C. Burke (2002). Influence of soil depth on the decomposition of Bouteloua gracilis roots in the shortgrass steppe. Plant and Soil 241:233-242.

Gillingham, K.T., S.J. Smith, and R.D. Sands (2007). Impact of bioenergy crops in a carbon dioxide constrained world: an application of the MiniCAM energyagriculture and land use model. Mitigation and Adaptation Strategies for Global Change, online first.

Goldewijk, K.K., and N. Ramankutty (2005). Land cover change over the last three centuries due to human activities: the availability of new global data sets. GeoJournal 61:335-344

Han, F.X.X., J.S. Lindner, and C.J. Wang (2007). Making carbon sequestration a paying proposition. Naturwissenschaften 94:170-182.

Hassink, J. (1997). The capacity of soils to preserve organic $\mathrm{C}$ and $\mathrm{N}$ by their association with clay and silt particles. Plant and Soil 191:77-87.

Hassink, J., and A.P. Whitmore (1997). A model of the physical protection of organic matter in soils. Soil Science Society of America Journal 61:131-139.

He, Z., T.J. Gentry, C.W. Schadt, L. Wu, J. Liebich, S.C. Chong, Z. Huang, W. Wu, B. Gu, P. Jardine, C. Criddle, and J. Zhou (2007). GeoChip: A comprehensive microarray for investigating biogeochemical, ecological, and environmental processes. International Society of Microbial Ecology Journal 1.

Huang, P.M.; M. Schnitzer (1986), Interactions of soil minerals with natural organics and microbes. Soil Science Society of America 17: Madison, WI. 
Hunt, H.W. (1977). A simulation model for decomposition in grassland. Ecology 58 (1977), pp. 469-484.

IPCC (2007). Climate Change 2007 - The Physical Science Basis. Contribution of Working Group I to the Fourth Assessment Report of the Intergovernmental Panel on Climate Change [Solomon, S., D. Qin, M. Manning, Z. Chen, M. Marquis, K.B. Averyt, M. Tignor and H.L. Miller (eds.)]. Cambridge University Press, UK, 996 pp.

IPCC Special Report on $\mathrm{CO}_{2}$ Capture and Storage (2005), A Special Report of Working Group 3, Intergovernmental Panel on Climate Change, Bert Metz, Ogunlade Davidson, Heleen de Coninck, Manuela Loos and Leo Meyer (eds.), Cambridge University Press, UK. pp. 431.

Jobbagy, E.G., and R.B.Jackson (2000). The vertical distribution of soil organic carbon and its relation to climate and vegetation. Ecological Applications 10:423-436.

Kahle, M., M. Kleber, and R. Jahn (2004). Retention of dissolved organic matter by phyllosilicate and soil clay fractions in relation to mineral properties. Organic Geochemistry 35:269-276.

Kandeler, E and RP Dick (2006). Soil Enzymes: Spatial Distribution and Function in Agroecosystems. Pages 263-286 in G Benckiser and S Schnell, editors. Biodiversity in Agricultural Production Systems. Taylor and Francis Publishing Group, New York NY.

Kazakov, A.E., M.J. Cipriano, P.S. Novichkov, S. Minovitsky, D.V. Vinogradov, A. Arkin, A.A. Mironov, M.S. Gelfand, and I. Dubchak (2006). RegTransBase-A database of regulatory sequences and interactions in a wide range of prokaryotic genomes. Nucleic Acids Res.

Kim, J.S., G. Sparovek, R.M. Longo, W.J. De Melo, and D. Crowley (2007). Bacterial diversity of terra preta and pristine forest soil from the Western Amazon. Soil Biology \& Biochemistry 39:684-690.

Kleber, M., C. Mertz, S. Zikeli, H. Knicker, and R. Jahn (2004). Changes in surface reactivity and organic matter composition of clay subfractions with duration of fertilizer deprivation. European Journal of Soil Science 55:381-391.

Kleber, M., R. Mikutta, M.S. Torn, and R. Jahn (2005). Poorly crystalline mineral phases protect organic matter in acid subsoil horizons. European Journal of Soil Science 56:717-725.

Krull, E.S., J.A. Baldock, and J.O. Skjemstad (2003). Importance of mechanisms and processes of the stabilization of soil organic matter for modelling carbon turnover. Functional Plant Biology 30: 207-222.

Kutchko, B.G., B.R. Strazisar, D.A. Dzombak, G.V. Lowry, and N. Thaulow (2007). Degradation of well cement by $\mathrm{CO}_{2}$ undner geologic sequestration conditions. Env. Sci. and Tech. 41: 4787-4792, 2007.

Kuzyakov, Y. (2006). Sources of $\mathrm{CO}_{2}$ efflux from soil and review of partitioning methods. Soil Biology \& Biochemistry 38: 425-448. 
Lehmann, J. (2007). Bio-energy in the black. Frontiers in Ecology and the Environment 5(7): 381-387.

Lehmann, J., D. Kern, B. Glaser, and W. Woods (2003). Amazonian Dark Earths: Origin, Properties, Management. Kluwer Academic Publishers, The Netherlands. 523 pp.

Lin, L.H., P.L. Wang, D. Rumble, J. Lippmann-Pipke, E. Boice, L.M. Pratt, B.S. Lollar, E.L. Brodie, T.C. Hazen, G.L. Andersen, T.Z. DeSantis, D.P. Moser, D. Kershaw, and T.C. Onstott (2006). Long-term sustainability of a high-energy, low-diversity crustal biome. Science 314:479-482.

Liu, N., G.M. Bond, A. Abel, B.J. McPherson, and J. Stringer (2005). Biomimetic sequestration of $\mathrm{CO}_{2}$ in carbonate form: Role of produced waters and other brines. Fuel Processing Technology 86: 1615-1625.

Lynch, J. M. and J. M. Whipps (1990). Substrate flow in the rhizosphere. Plant and Soil 129: $1-10$.

Maggi F., C. Gu, W.J. Riley, G.M. Hornberger, R.T. Venterea, T. Xu, N. Spycher, C. Steefel, N.L. Miller, and C.M. Oldenburg (2008). Mechanistic modeling of nitrogen cycling and losses. Journal of Geophysical Research—Biogeosciences (in press).

Marin-Spiotta, E., R. Ostertag, and W. L. Silver. 2007. Long term patterns in reforestation of tropical pastures: plant community composition and aboveground biomass accumulation. Ecological Applications 17: 828-839.

Marin-Spiotta, E., C. W. Swanston, M. S. Torn, W. L. Silver, and S. D. Burton (2008). Chemical and mineralogical control of soil carbon storage during tropical reforestation. Geoderma (in press).

Masiello, C.A., O.A. Chadwick, J. Southon, M.S. Torn, and J.W. Harden (2004). Weathering controls on mechanisms of carbon storage in grassland soils. Global Biogeochemical Cycles 18(4): GB4023 10.1029/2004GB002219

Mayer, L.M. (1994). Relationships between mineral surfaces and organic carbon concentrations in soils and sediments. Chemical Geology 114:347-363.

Mayer, L.M. (1994). Surface area control of organic carbon accumulation in continental shelf sediments. Geochimica et Cosmochimica Acta 58:1271-1284.

Mertz, C., M. Kleber, and R. Jahn (2005). Soil organic matter stabilization pathways in clay sub-fractions from a time series of fertilizer deprivation. Organic Geochemistry 36:1311-1322.

Mikutta, R. M. Kleber, M.S. Torn, and R. Jahn (2006). Stabilization of soil organic matter: association with minerals or chemical recalcitrance? Biogeochemistry $77: 25-56$

Mikutta, R., M. Kleber, and R. Jahn (2005). Poorly crystalline minerals protect organic carbon in clay subfractions from acid subsoil horizons. Geoderma 128:106-115. 
Mitchell, A.C., A. Phillips, M. Hamilton, R. Gerlach, J. Kuszuba, A. Cunningham (2007, submitted). Resilience of Bacillus mojavensis planktonic and biofilm communities to supercritical $\mathrm{CO}_{2}$. Journal of Supercritical Fluids.

Nettleton, W. D., ed. (1991). Occurrence, characteristics, and genesis of carbonate, gypsum, and silica accumulations in soils. Soil Science Society of America, Special Publication vol. 26, Madison, WI.

Nordbotten, J.M., M.A. Celia, S. Bachu, and H.K. Dahle (2005). Semi-analytical solution for $\mathrm{CO}_{2}$ leakage through a well. Env. Sci. and Tech. 39: 602-611.

Omoike, A., and J. Chorover (2006). Adsorption to goethite of extracellular polymeric substances from Bacillus subtilis. Geochimica et Cosmochimica Acta 70:827-838.

Onstott, T.C. (2004). Impact of $\mathrm{CO}_{2}$ injections on deep subsurface microbial ecosystems and potential ramifications for the surface biosphere. In: Carbon Dioxide Capture for Storage in Deep Geological Formation, edited by D.C. Thomas, and S.M. Benson.

Parton, W., W.L. Silver, I.C. Burke, L. Grassens, M.E. Harmon, W.S. Currie, J.Y. King, E.C. Adair, L.A. Brandt, S.C. Hart, and B. Fasth (2007). Global-scale similarities in nitrogen release patterns during long-term decomposition. Science 315:361-364.

Parton, W.J., M. Hartman, D. Ojima, and D. Schimel (1998). DAYCENT and its land surface submodel: Description and testing. Global and Planetary Change 396:1-14.

Paustian, K., C.V. Cole, D. Sauerbeck, and N. Sampson (1998). CO 2 mitigation by agriculture: An overview. Climate Change 40:135-162.

Pruess, K., C.M. Oldenburg and G.J. Moridis (1999). TOUGH2 User's Guide Version 2. E. O. Lawrence Berkeley National Laboratory Report LBNL-43134.

Rasmussen, C., M.S. Torn, and R.J. Southard (2005). Mineral assemblage and aggregates control carbon dynamics in a California conifer forest. Soil Science Society of America Journal 69:1711-1721.

Rasse, D. P., C. Rumpel, and M. F. Dignac (2005). Is soil carbon mostly root carbon? Mechanisms for a specific stabilisation. Plant and Soil 269, 341-356.

Rendig, V. V., H.M. Taylor (1989). Principle of Soil-Plant Interrelationships. McGrawHill: New York.

Righelato, R. and D. V. Spracklen (2007). Environment-Carbon mitigation by biofuels or by saving and restoring forests? Science 317(5840): 902-902.

Saggar, S., Parshotam, A., Sparling, G. P., Feltham, C. W., and P.B.S. Hart (1996). 14Clabelled ryegrass turnover and residence times in soils varying in clay content and mineralogy. Soil Biology and Biochemistry 28:1677-1686.

Sedjo, R.A., B.L. Sohngen, and R.O. Mendelsohn (2001). Estimating Carbon Supply Curves for Global Forests and Other Land Uses Resources For the Future. Washington DC.

Shainberg, I.; J. Shalhevet, (eds.) (1984). Soil Salinity under Irrigation. Springer-Verlag: Berlin, 51. 
Silver, W.L., R. Ostertag, and A.E. Lugo. 2000. The potential for carbon sequestration through reforestation of tropical agricultural and pasture lands. Restoration Ecology 8:394-407.

Silver, W.L., L. Kueppers, A. E. Lugo, R. Ostertag, and V. Matzek. 2004. Carbon sequestration and plant community dynamics with reforestation of tropical pasture. Ecological Applications 14: 1115-1127.

Simpson, A. J., M.J. Simpson, E. Smith, and B.P. Kelleher (2007). Microbially derived inputs to soil organic matter: Are current estimates too low? Environmental Science \& Technology 41:8070-8076.

Simsek-Ege, F.A., G.M. Bond, and J. Stringer (2002a). Polyelectrolyte complex cages for a novel biomimetic $\mathrm{CO}_{2}$ sequestration system. In: Environmental Challenges and Greenhouse Gas Control for Fossil Fuel Utilization in the 21st Century, MarotoValer et al. (eds.), Kluwer Academic Publishers, 133-146.

Simsek-Ege, F.A.,, G.M. Bond, and J. Stringer (2002b). Matrix molecular weight cut-off for encapsulation of carbonic anhydrase in polyelectrolyte beads. J. Biomater. Sci. Polymer Edn. 13:1175-1187.

Six, J., R.T. Conant, E.A. Paul, and K. Paustian (2002). Stabilization mechanisms of soil organic matter: Implications for C-saturation of soils. Plant and Soil 241:155-176.

Six, J., S.M. Ogle, F.J. Breidt, R.T. Conant, A. Mosier, and K. Paustian (2004). The potential to mitigate global warming with no-tillage management is only realized when practised in the long term. Global Change Biology 10:155-160.

Sohngen, B., R. Mendelsohn, and R. Sedjo (2001). A global model of climate change impacts on timber markets. Journal of Agricultural and Resource Economics 26(2): 326-343.

Stevenson, F.J. (1982). Humus Chemistry, Genesis, Composition, Reactions. Wiley, New York.

Stringer, J., and G.M. Bond (2007). Mineralization as a method for carbon sequestration. Paper presented at the Materials Science \& Technology 2007 Conference and Exhibit (MS\&T '07), Detroit, MI, September 16-20, 2007.

Subak, S. (2002). Forest protection and reforestation in Costa Rica: Evaluation of a clean development mechanism prototype. Environmental Management 26(3).

Sullivan, L.A. and J.F. Parr (2007). Green geosequestration: Secure carbon sequestration via plant silica biomineralization. Goldschmidt Conference, Cologne, Germany.

Swanston, C.W., M.S. Torn, P.J. Hanson, J.R. Southon, C.T. Garten, E.M. Hanlon, and L. Ganio (2005). Characterizing processes of soil carbon stabilization using forest stand-level radiocarbon enrichment. Geoderma 128:52-62.

Theng, B.K.G. (1979). Formation and properties of clay-polymer complexes Elsevier Science Publishing Co.

Torn, M.S., S.E. Trumbore, O.A. Chadwick, P.M. Vitousek, and D.M. Hendricks (1997). Mineral control of soil organic carbon storage and turnover. Nature 389: 170-173. 
Trumbore, S.E., Davidson, E.A., Barbosa de Camargo, P., Nepstad, D.C. and Martinelli, L.A., 1995. Belowground cycling of carbon in forests and pastures of Eastern Amazonia. Global Biogeochemical Cycles, 9(4): 515-528.

U.S. DOE (1999). Working paper on carbon sequestration science and technology, Office of Science and Office of Fossil Energy, DOE.

U.S. DOE NETL (2006). Carbon Sequestration Roadmap and Program Plan.

von Lutzow, M., I. Koegel-Knabner, K. Ekschmitt, E. Matzner, G. Guggenberger, B.

Marschner, and H. Flessa (2006). Stabilization of organic matter in temperate soils: mechanisms and their relevance under different soil conditions - a review. European Journal of Soil Science 57:426-445.

Wright, J., A. Colling, Open University Course Team (1995). Seawater: Its Composition, Properties and Behavior, $2^{\text {nd }}$ Edition, Pergamon-Elsevier, Oxford.Xu, T, J. A. Apps, and K. Pruess (2005). Mineral sequestration of carbon dioxide in a sandstone-shale system. Chemical Geochemistry, 217(3-4): 295-318.

Zimov, S.A., Schuur, E.A.G. and Chapin III, F.S., 2006. Permafrost and the Global Carbon Budget. Science, 312(5780): 1612-1613. 


\section{FiguRES}

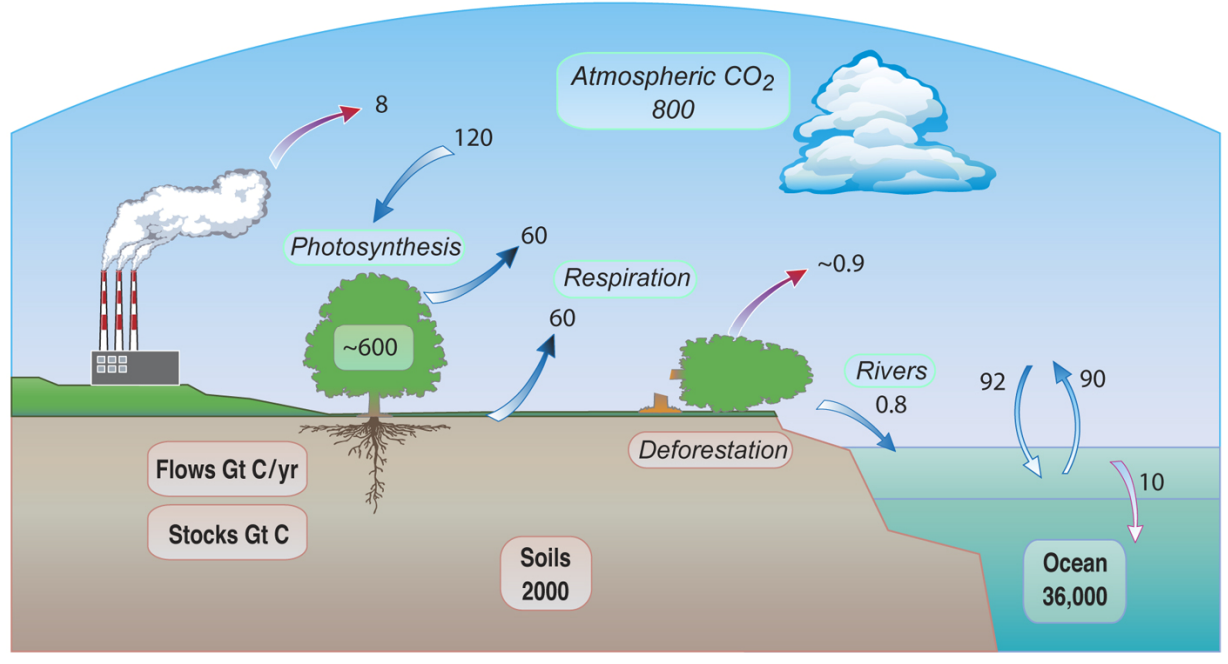

Figure 1. Global Carbon Cycle. Stocks and flows as of 2007 (Torn and Denn, personal communication).

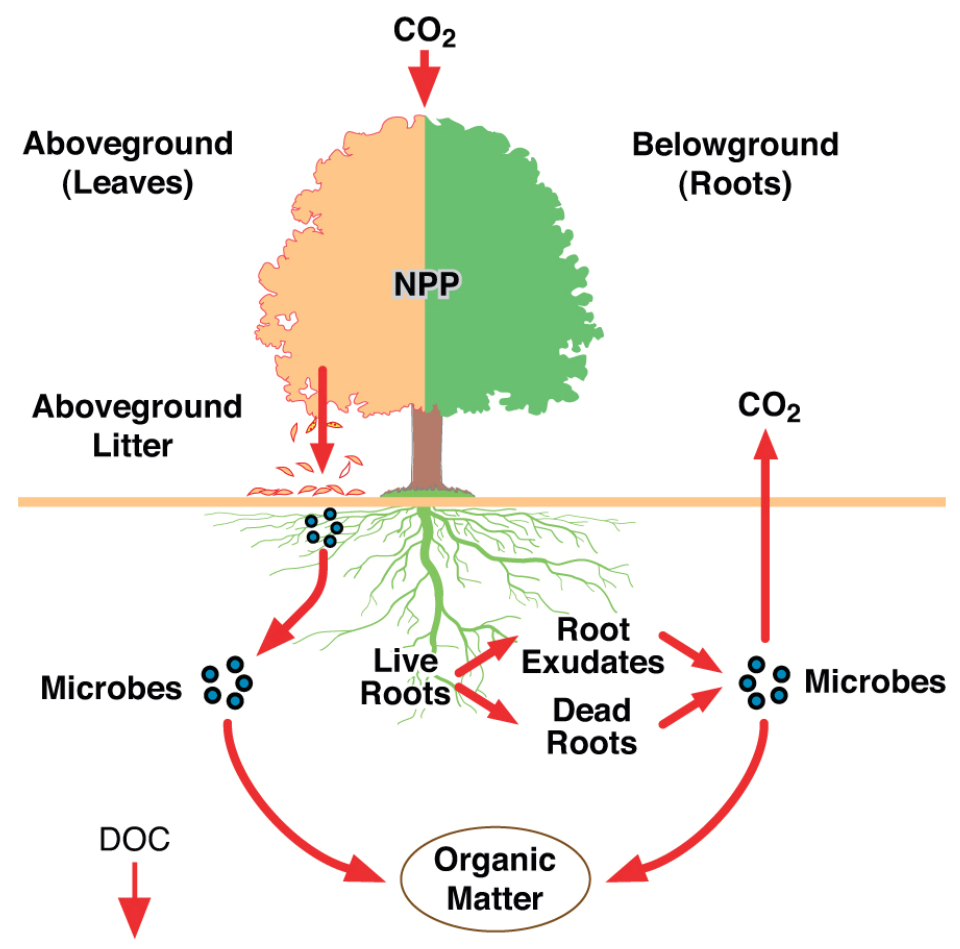

Figure 2. Schematic diagram of terrestrial $\mathrm{C}$ cycling highlights the processes targeted for sequestering $\mathrm{CO}_{2}$ from the atmosphere and into soils (Torn and Denn, personal communication). 


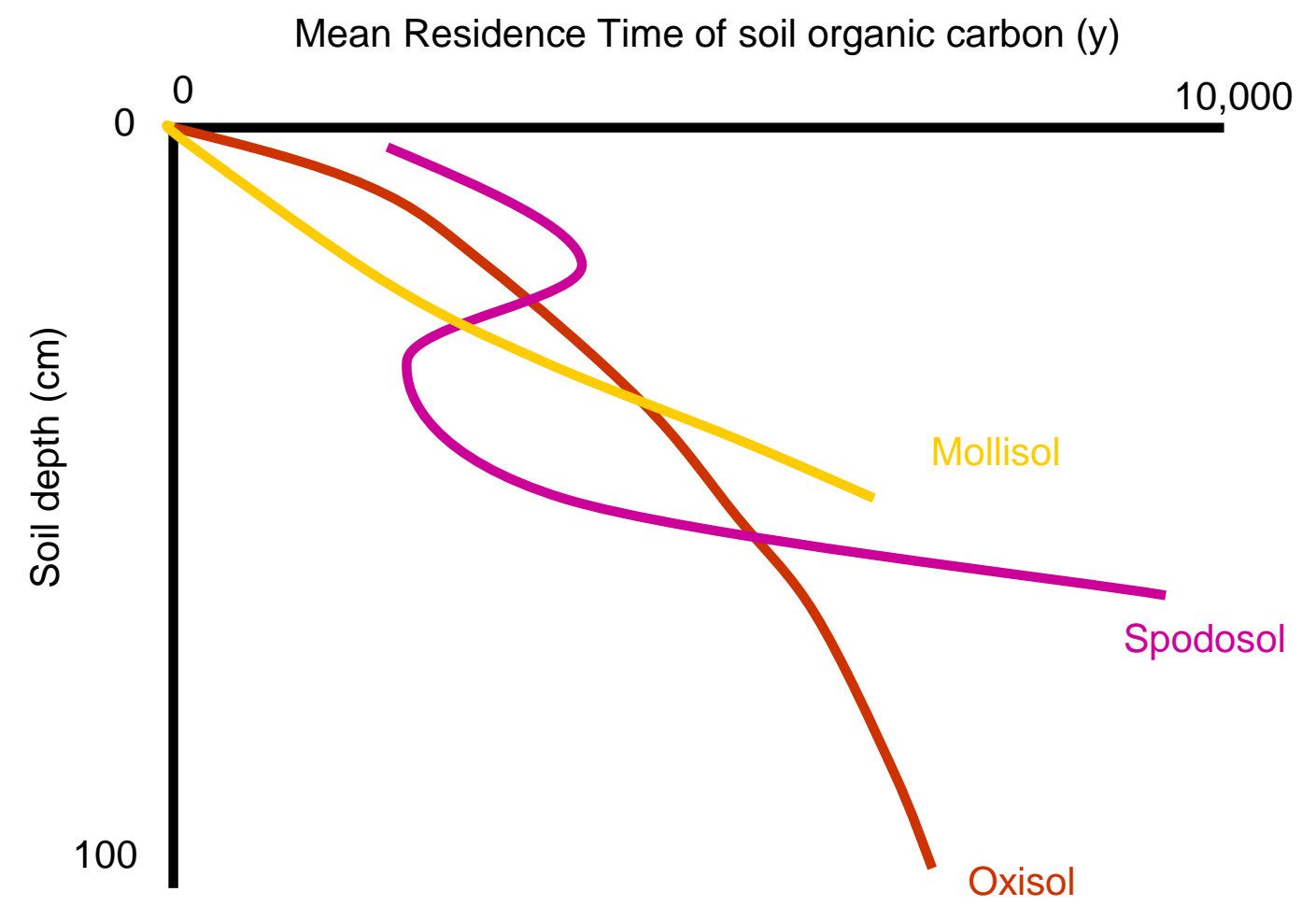

Figure 3. Idealized representation of data from Trumbore (2006), showing that mean radiocarbon age increases with depth. Mollisol, Spodosol, and Oxisol are soil orders chosen to illustrate the differences in organic matter stability associated with different mineralogy and leaching conditions. 


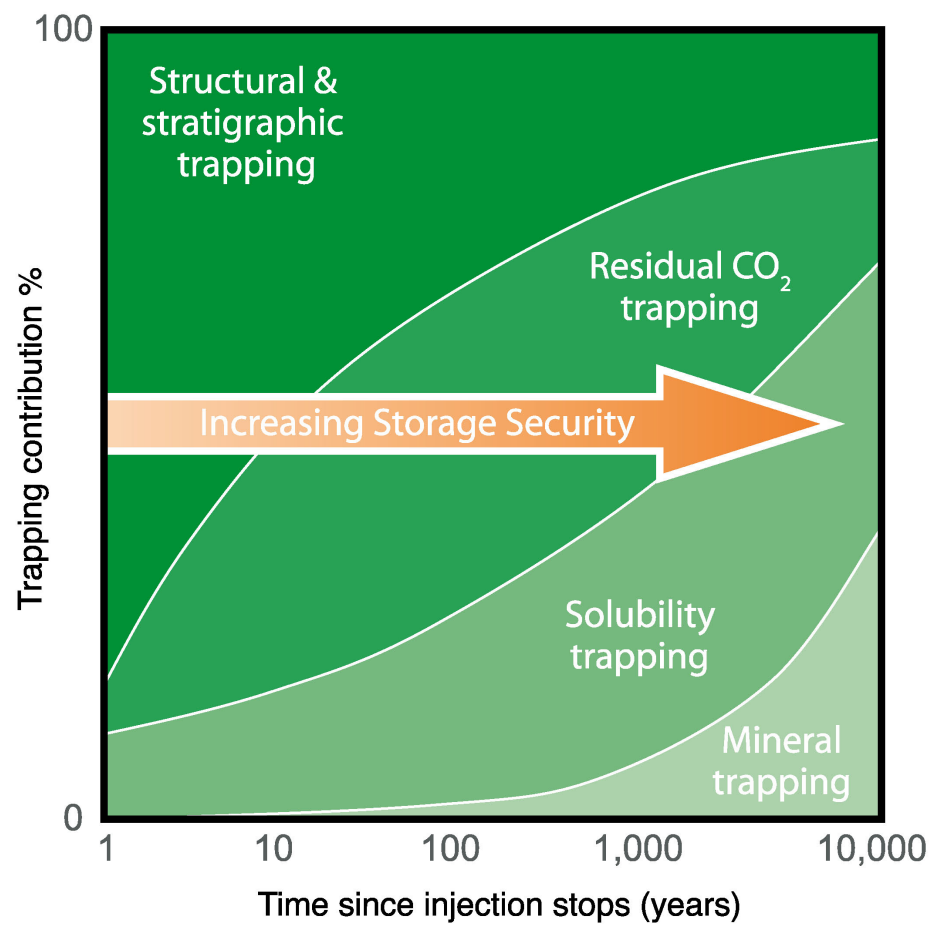

Figure 4. Storage mechanisms as a function of time following injection (IPCC, 2005).

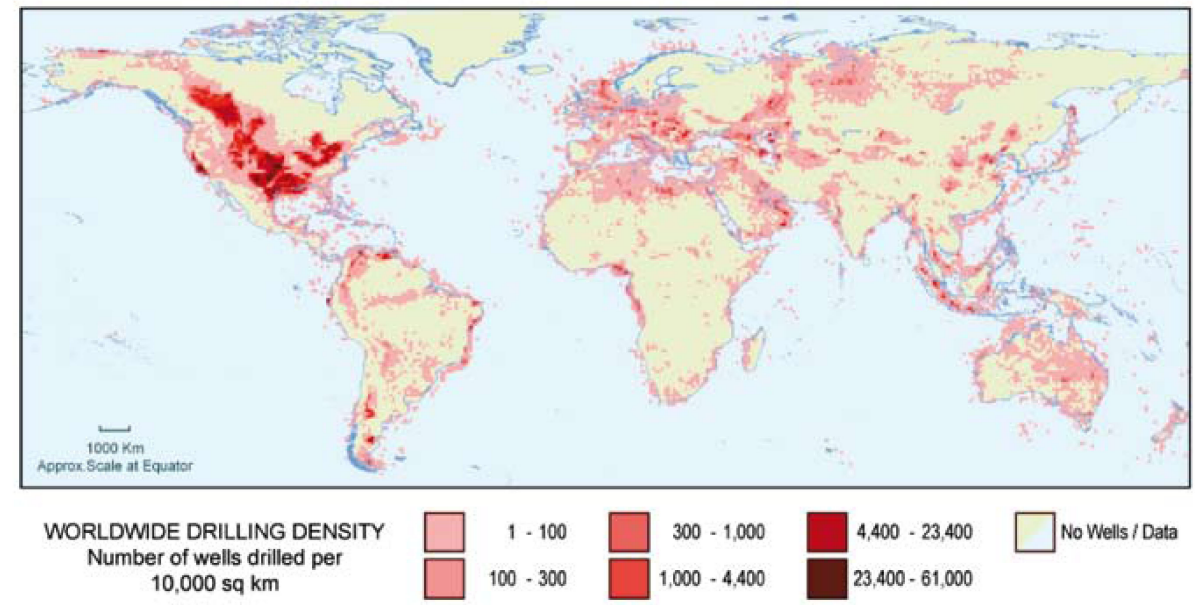

Figure 5. Well density worldwide relevant to potential leakage from geologic storage sites (IPCC, 2005). 


\begin{tabular}{lcc}
\hline Reservoir type & $\begin{array}{c}\text { Lower estimate of storage capacity } \\
\left(\mathbf{G t C O}_{2}\right)\end{array}$ & $\begin{array}{c}\text { Upper estimate of storage capacity } \\
\left(\mathbf{G t C O}_{2}\right)\end{array}$ \\
\hline Oil and gas fields & $675^{\mathrm{a}}$ & $900^{\mathrm{a}}$ \\
Unminable coal seams (ECBM) & $3-15$ & 200 \\
Deep saline formations & 1,000 & Uncertain, but possibly $10^{4}$ \\
\hline
\end{tabular}

${ }^{\text {a }}$ These numbers would increase by $25 \%$ if 'undiscovered' oil and gas fields were included in this assessment.

Figure 6. Capacity estimates for various GCS sites (IPCC, 2005). 
Table 1. Materiality of various carbon sequestration (CS) approaches and biological enhancements.

\begin{tabular}{|c|c|c|c|c|}
\hline $\begin{array}{l}\text { CS } \\
\text { approach }\end{array}$ & $\begin{array}{l}\text { Reservoir type or } \\
\text { Ecosystem }\end{array}$ & $\begin{array}{l}\text { Biological enhancement } \\
\text { research focus }\end{array}$ & $\begin{array}{l}\text { Incremental seq. } \\
\text { potential }\end{array}$ & Benefits and synergies \\
\hline GCS & $\begin{array}{l}\text { Depleted } \\
\text { hydrocarbon } \\
\text { reservoirs and saline } \\
\text { formations }\end{array}$ & $\begin{array}{l}\text { Mitigate well cement } \\
\text { degradation using biofilms } \\
\text { or enzymatic mineral } \\
\text { trapping. }\end{array}$ & $\begin{array}{l}>675 \mathrm{Gt} \mathrm{CO}_{2} \text { worldwide } \\
\text { capacity }\end{array}$ & $\begin{array}{l}\text { Decreases well leakage effectively to } \\
\text { zero. }\end{array}$ \\
\hline GCS & $\begin{array}{l}\text { Saline formations, } \\
\text { depleted water-drive } \\
\text { gas reservoirs, and } \\
\text { depleted oil } \\
\text { reservoirs }\end{array}$ & $\begin{array}{l}\text { Increase carbonate mineral } \\
\text { reaction kinetics by } \\
\text { microbial manipulation }\end{array}$ & $\begin{array}{l}\text { Faster permanence } \\
\text { alleviates leakage concern } \\
\text { potentially opening up } \\
\text { huge opportunities for } \\
\text { GCS. }\end{array}$ & $\begin{array}{l}\text { Reactions use cations favoring } \\
\text { dissolution and enhancing porosity. } \\
\text { Mineral trapping achieved in } 100 \\
\text { years compared to } 5000 \text { years } \\
\text { without enhancement. }\end{array}$ \\
\hline $\begin{array}{l}\text { Above- } \\
\text { ground } \\
\text { CCS }\end{array}$ & $\begin{array}{l}\text { Surface processing of } \\
\text { flue gas with mineral } \\
\text { trapping }\end{array}$ & $\begin{array}{l}\text { Enzymatic enhancement of } \\
\text { bicarbonate speciation }\end{array}$ & $\begin{array}{l}\text { Potentially large, e.g., } \\
\text { could sequester } \sim 57 \% \text { of } \\
\text { Permian Basin's } \mathrm{CO}_{2} \\
\text { production from } \\
\text { electricity generation. }\end{array}$ & $\begin{array}{l}\text { Creates a use for oil-field brines that } \\
\text { cause surface-water disposal } \\
\text { problem. } \\
\text { Potential use for agricultural waste } \\
\text { products such as alkaline fly ash, } \\
\text { ammonia, and urea. } \\
\text { Mineral trapping is considered } \\
\text { permanent even above ground. }\end{array}$ \\
\hline $\begin{array}{l}\text { Terrestrial } \\
\text { CS }\end{array}$ & $\begin{array}{l}\text { Forests managed for } \\
\text { C offsets }\end{array}$ & $\begin{array}{l}\text { Change in land cover type } \\
\text { or management practice. } \\
\text { Managing deep soil C, e.g., } \\
\text { by promoting deep-roots C } \\
\text { inputs }\end{array}$ & $\begin{array}{l}\text { Estimated } 500 \mathrm{Tg} \mathrm{C} / \mathrm{y} \text { or } \\
15-150 \mathrm{Pg} \mathrm{C} \text { over } 100 \\
\text { years }\end{array}$ & $\begin{array}{l}\text { Habitat preservation, increased soil } \\
\text { fertility, water holding capacity } \\
\text { (WHC) for water supply and flood } \\
\text { management }\end{array}$ \\
\hline Terrestrial & Forests managed for & Deep soil C & 1-10 Pg C/yr (NETL & Habitat preservation, increased soil \\
\hline
\end{tabular}




\begin{tabular}{|c|c|c|c|c|}
\hline $\mathrm{CS}$ & timber and other uses & Deeper roots & 2006) & fertility and water holding capacity. \\
\hline $\begin{array}{l}\text { Terrestrial } \\
\text { CS }\end{array}$ & $\begin{array}{l}\text { Rangeland, } \\
\text { restoration, \& other } \\
\text { grassland }\end{array}$ & $\begin{array}{l}\text { Inorganic carbonate, } \\
\text { Deep soil C, } \\
\text { Deeper roots }\end{array}$ & $\begin{array}{l}1.2+/-0.5 \mathrm{Pg} \mathrm{C}, \text { from } \\
\text { grasslands and } \sim 2 \mathrm{Gt} \mathrm{C} \\
\text { from reclaimed mine land } \\
\& \text { wetlands }\end{array}$ & $\begin{array}{l}\text { Increased soil fertility, water holding } \\
\text { capacity, erosion prevention, positive } \\
\text { community benefit from mixed use of } \\
\text { lands }\end{array}$ \\
\hline $\begin{array}{l}\text { Terrestrial } \\
\text { CS }\end{array}$ & Agriculture & $\begin{array}{l}\text { Deep soil C, } \\
\text { Deeper roots, } \\
\text { Plant tissue chemistry, } \\
\text { Microbial community, } \\
\text { Adding black carbon }\end{array}$ & $0.85-0.9 \mathrm{Pg} \mathrm{C} / \mathrm{yr}$ & $\begin{array}{l}\text { Improved soil and water quality, } \\
\text { decreased nutrient loss from soil } \\
\text { resulting in improved soil fertility } \\
\text { and water holding capacity. Deep } \\
\text { roots exude labile C that may } \\
\text { destabilize deep soil C. }\end{array}$ \\
\hline $\begin{array}{l}\text { Terrestrial } \\
\text { CS }\end{array}$ & Bio-energy crops & $\begin{array}{l}\text { Deep soil C, } \\
\text { Deeper roots, } \\
\text { Plant tissue chemistry, } \\
\text { Microbial community, } \\
\text { Adding black carbon }\end{array}$ & $0.5-0.8 \mathrm{Pg} \mathrm{C} / \mathrm{yr}$ & $\begin{array}{l}\text { In addition to items mentioned above, } \\
\text { black } C \text { is an effective soil fertility } \\
\text { amendment in many soils. }\end{array}$ \\
\hline $\begin{array}{l}\text { Terrestrial } \\
\text { CS }\end{array}$ & $\begin{array}{l}\text { Loss of Soil C due to } \\
\text { land use/land cover } \\
\text { change (LULCC) }\end{array}$ & & $\begin{array}{l}\text { Upper estimate of loss of } \\
200 \mathrm{Mg} \mathrm{C} \mathrm{ha}{ }^{-1} \text { over } 30 \\
\text { years, but most in the first } \\
2 \text { years post conversion }\end{array}$ & $\begin{array}{l}\text { Better understanding of soil } \\
\text { vulnerability could help with siting } \\
\text { and managing land conversion. } \\
\text { Integrated assessment could create } \\
\text { generalizable methods for } \\
\text { verification and certification of C } \\
\text { sequestration. }\end{array}$ \\
\hline
\end{tabular}

Data sources: US DOE NETL 2006; Righelato and Spracklen 2007; Edmonds et al. 2004; Gillingham et al. 2007 ; US DOE 1999. $1 \mathrm{Pg}=1 \mathrm{Gt}=10^{15} \mathrm{~g} .1 \mathrm{~g} \mathrm{C}=3.7 \mathrm{gCO}_{2}$. 